\title{
PRODUCTION AND DESIGN YARN POLYOLEFIN BY SPECIFICATIONS MECHANICAL FOR SUITABLE END USE.
}

\author{
by \\ Dr. Sayed Takey Mohamed Abd Elmaksoud \\ Lecture in Department of Textile Industrial \\ Faculty of Industrial Education \\ Suez Canal University \\ PROF.ASS.Ashraf Abd Elfatah Mostafa \\ Prof.ass. In Department of Art Education \\ Faculty of Specific Education \\ El-Mansoura University.
}

مجلة بحوث التربية النوعية - جامعة المنصورة

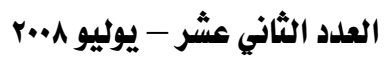


ב Production and Design Yarn Polyolefin by Specifications Mechanical. $=$ 


\title{
Production and Design Yarn Polyolefin by Specifications Mechanical for Suitable End Use.
}

PROF.ASS.Ashraf Abd Elfatah Mostafa

\begin{abstract}
Wheat flour, mung bean flour, chickpeas flour and dried skim milk were mixed with different levels to produce biscuits (protein-rich). Chemical composition, food energy, essential amino acids comparing to FAO/WHO reference patterns, protein efficiency ratio and biological value were evaluated. Organoleptic evaluation was done for all biscuit samples. It was noted that the highest amounts of protein was found in dried skim milk supplementation followed by mung bean and chickpeas flours (35.7, 31.7 and 21.83 g./ $/ 100 \mathrm{~g}$.) respectively as compared with wheat flour (21.8g./100g.). As a result of adding dried skim milk, mung bean flour and chickpeas flour gave the higher protein value $(108.92,110.81,115.96$, 116.30, 119.82 and $123.60 \%$ ) of samples No. 1, 3, 5, 2, 6, and 4, respectively comparing with control sample. On the other hand, the composition of the biscuits provided a good caloric values i.e. 396.70 to $399.10 \mathrm{~K}$.cal $/ 100 \mathrm{~g}$. sample for the 3 and 4 treatments as a results of adding chickpeas flour 5 and $10 \%$ with dried skim milk 5\%, respectively. It could be noticed that the concentration level of essential amino acids of fortified biscuit samples were increased and the percentage of total essential amino acids were raised (103.82 to $116.29 \%)$ as compared with control. The lowest level of covered the daily requirements of total essential amino acids was in control sample $(76.90 \%)$ and increased to $(89.44 \%)$ in sample No. 4 which contained (10\% of mung bean flour and $5 \%$ of dried skim milk), also $112 \mathrm{~g}$. from this sample covered the daily requirements of total essential amino acids. On the other hand, adding mung bean flour, chickpeas flour and dried skim milk, protein efficiency ratio and biological value were improved up to $(111.20 \%$ and $104.22 \%)$ respectively. Evaluation of organoleptic test clearly indicated that a significant increase of taste, crispiness, color and acceptable of biscuit samples especially in 4 and 5 treatments $(10 \%$ mung bean and $10 \%$ chickpeas flours. Finally, results indicated that addition of mung bean flour and chickpeas flour at different levels were optimal for preparation of biscuits.
\end{abstract}


يعتبر تصميهم وتصنيع هذه النوعية من المنتجـات النسيجية عمليـة متعـددة الجوانب تحتـاج

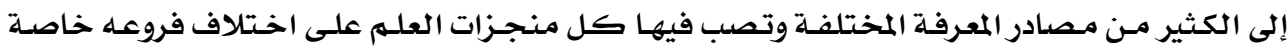

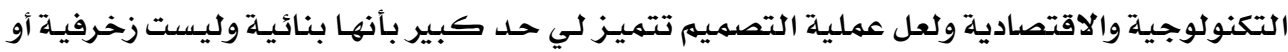

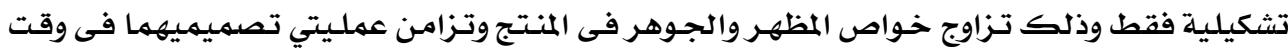

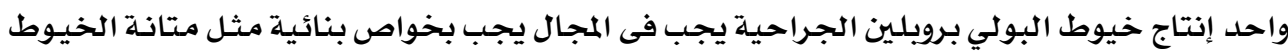

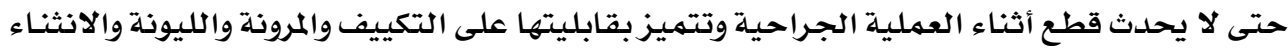
فى يد الجراح.

ومن الدراسـات الميدانيـة فى مجـال إنتاج المستلزمات الطبيـة يجـب توفير الخيوط الجراحيـة

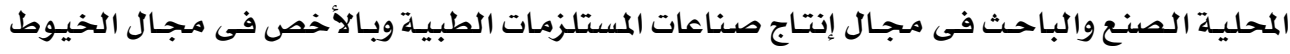

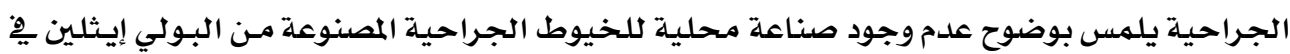

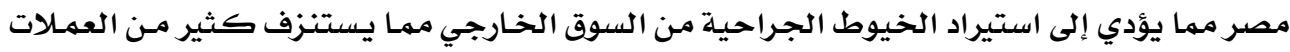

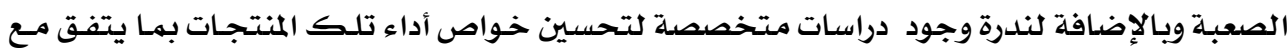

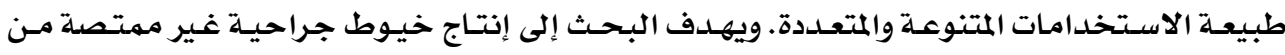

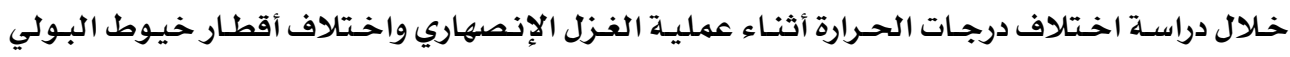

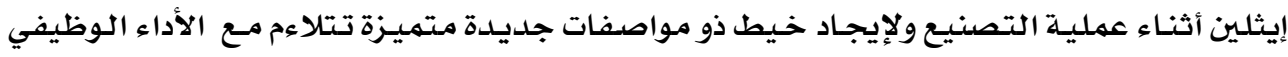

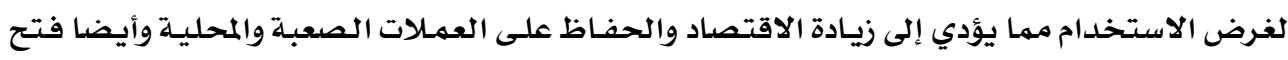

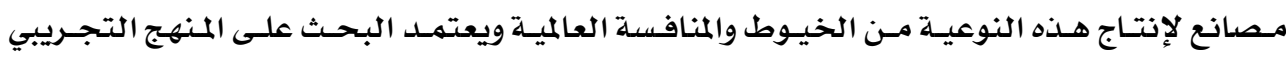

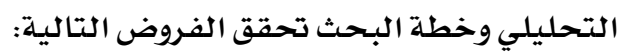

ا - دراسـة درجـات الحـرارة فى عمليـة الانصهار للخامسة البـولي بـروبلين لها تأثير على خـواص

$$
\text { الخيوط الجراحية . }
$$

r- دراسـة قطرا لخيط لخامة البولي بروبلين لها تأثير على خواص الخيوط الجراحية .

وهـذا البـحـث غطي الجوانب النظريـة والعمليـة التجريبيـة والتطبيقيـة لهذا الموضـوع على التى

$$
\text { أساس تحليلي لكل من الجوانب التطبيقية. }
$$

وتم دراسـة تأثير العوامـل محسل الدراسـة على الخـواص المختلفـة التي تهم دراسـتها مثل تأثير

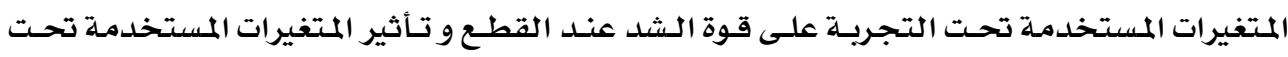

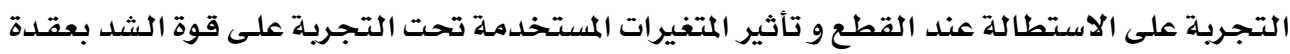

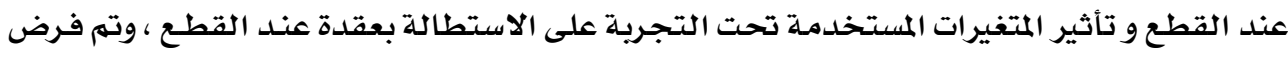

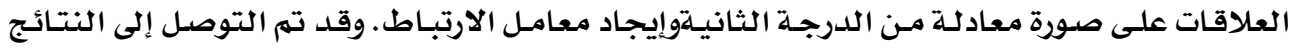

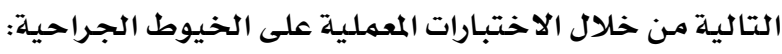




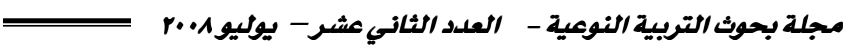

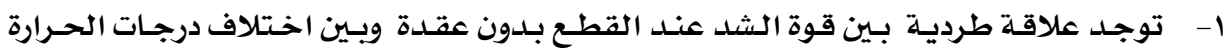

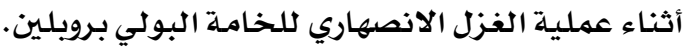

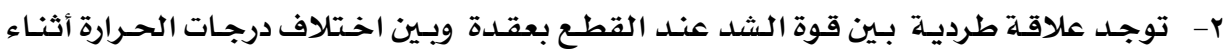

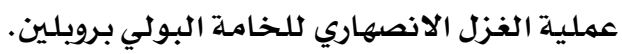

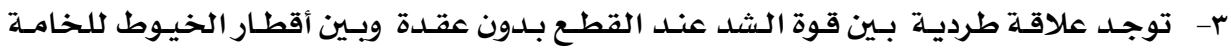
البولي بروبلين.

ع- توجد علاقة طردية بين قوة الشد عند القطـع بعقدة وبـين أقطـار الخيـوط للخـامسة البـولي بروبلين. ه- توجد علاقة عكسية بـين الاستطالة عنــ القطـع بـدون عقدة وبـين اخـتلاف درجـات الحـرارة أثناء عملية الغزل الانصهاري للخامسة البولي بروبلين.

؟- توجد علاقة عكسية بين الاستطالة عنـد القطع بعقدة وبـين اختلاف درجـات الحـرارة أثنـاء

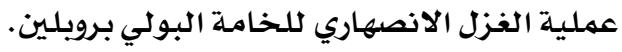

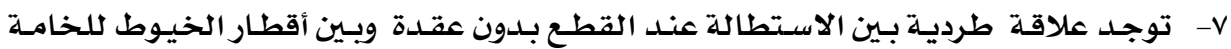
البولي بروبلين.

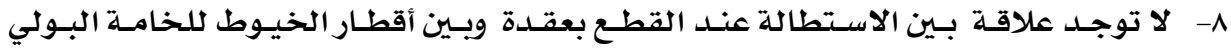
بروبلين. 


\section{1- INTRODUCTION}

Textile has swept over new fields the last three decades. It has been used indifferent fields, such as agriculture, industry and medicine, with the aim of improving the performance efficiency and reducing costs. This industry has recently achieved a tremendous success in medical fields thus, it has been used in designing and manufacturing polyproplene suture.

Propylene $(\mathrm{CH} 2=\mathrm{CH}-\mathrm{CH} 3)$, the by- product of the oil refineries, is one of the constituents obtained from thermal or catalytic cracking of petroleum . Under suitable polymerising conditions. Propylene produces fiber-forming. Propylene.

Spinning : polypropylene is spun by melt spinning .because it is a cheap process. Further, since the polymer has high degree of polymerization, it is difficult to dissolve in organic solvents. the filaments, extruded at $1000 \mathrm{c}$ above the melting point, are cooled in air chamber or tank of water and collected on bobbins. Rapid cooling or quenching produces small crystals . in contrast to lager crystals formed by slow cooling. The filaments are the hot- drawn and twisted into yarns ${ }^{(1)}$.

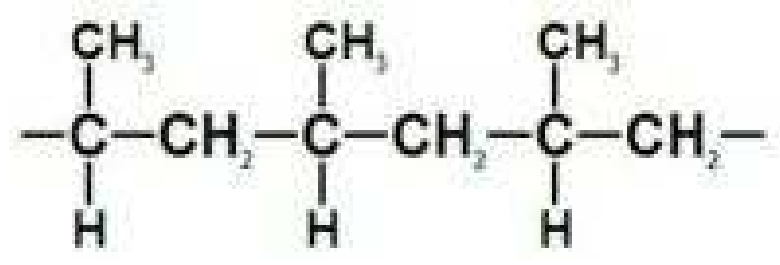

Figure(1): Polyproplene Suture

Properties of poly propylene $\mathrm{e}^{(2)}$ :

Tenacity

Elongation

Abrasion Resistance

Absorbency

Thermal Retention

Resiliency

Elastic Recovery
High.

Variable

Very Good

Low

Good

Excellent

Excellent 
Physicians have used sutures for at least 4,000 years. Archaeological records from ancient Egypt show that Egyptians used linen and animal sinew to close wounds ${ }^{(15),(16)}$. In ancient India, physicians used the heads of beetles or ants to effectively staple wounds shut. The live creatures were affixed to the edges of the wound, which they clamped shut with their pincers. Then the physician cut the insects' bodies off, leaving the jaws in place. Other natural materials doctors used in ancient times were flax, hair, grass, cotton, silk, pig bristles, and animal gut. Though the use of sutures was widespread, sutured wounds or incisions often became infected. Nineteenth century surgeons preferred to cauterize wounds, an often ghastly process, rather than risk the patient's death from infected sutures. The great English physician Joseph Lister discovered disinfecting techniques in the 1860 s, making surgery much safer. Lister soaked catgut suture material in phenol making it sterile, at least on the outside. Lister spent over 10 years experimenting with catgut, to find a material that was supple, strong, sterilizable, and absorbable in the body at an adequate rate. A German surgeon made advances in the processing of catgut early in the twentieth century, leading to a truly sterile material.

Catgut was the staple absorbable suture material through the 1930s, while physicians used silk and cotton where a non-absorbable material was needed. Suture technology advanced with the creation of nylon in 1938 and of polyester around the same time. As more man-made textiles were developed and patented for suture use, needle technology also advanced. Surgeons began using an atraumatic needle, which was pressed or crimped onto the suture. This saved the trouble of threading the needle in the operating room, and allowed the entire needle diameter to remain roughly the same size as the suture itself. In the 1960s, chemists developed new synthetic materials that could be absorbed by the body. These were polyglycolic acid and polylactic acid. Previously, absorbable sutures had to be made from the natural material catgut. Synthetic absorbable suture material is now far more prevalent than catgut in United States hospitals.

The FDA began requiring approval of new suture material in the 1970s. A Medical Device Amendment was added to the FDA in 1976, and suture manufacturers have been required to seek pre-market approval for new sutures since that time. Manufacturers must comply with specific Good Manufacturing Practices, and guarantee that their products are safe and effective. Patents for new suture materials are granted for 14 years. 
Natural sutures are made of catgut or reconstituted collagen, or from cotton, silk, or linen. Synthetic absorbable sutures may be made of polyglycolic acid, a glycolide-lactide copolymer; or polydioxanone, a copolymer of glycolide and trimethylene carbonate. These different polymers are marketed under specific trade names. Synthetic nonabsorbable sutures may be made of polypropylene, polyester, polyethylene terephthalate, polybutylene terephthalate, polyamide, different proprietary nylons, or Goretex. Some sutures are also made of stainless steel.

Sutures are often coated, especially braided or twisted sutures. They may also be dyed to make them easy to see during surgery. Only FDA approved dyes and coatings may be used. Some allowable dyes are: logwood extract, chromium-cobalt-aluminum oxide, ferric ammonium citrate pyrogallol, D\&C Blue No. 9, D\&C Blue No. 6, D\&C Green No. 5, and D\&C Green No. 6. The coatings used depend on whether the suture is absorbable or nonabsorbable. Absorbable coatings include Poloxamer 188 and calcium stearate with a glycolide-lactide copolymer. Nonabsorbable sutures may be coated with wax, silicone, fluorocarbon, or polytetramethylene adipate.

It has been suggested that polyproplene sutures are easier to tie than monofilament nylon and that the knots hold more securely ${ }^{(13),(14),(5)}$.

Used in over 1000 million surgical procedures, monofilament polyproplene suture has been proven important qualities and characteristics including:

1-pliability.

2-easy knot tying, with excellent knot security.

3-exceptional surface smoothness, resulting in easy passage through tissue.

4-biological inertness, eliciting only minimal tissue reaction.

5- monofilament construction, providing no harbour for bacteria.

6-considerably less than thrombogenicity than many other suture materials.

7-non-biodegradable;providing prolonged tensile strength retention in tissue after implantation, even the presence of infection.

8-non absorbable

9- monofilament polyproplene the standard for vascular surgery. ${ }^{(11)}$ 


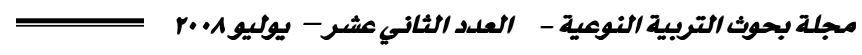

Production of polypropylene suture is circle figure:

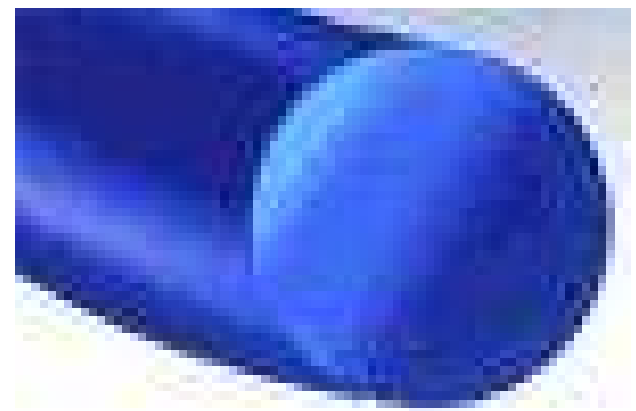

Figure(2):Cross Section Of Polypropylene Suture

\section{2-MAGNITUDE OF PROPLEM RESEARCH:}

As result of increasing number of patients, hospitals, and number of operations rooms which needs medical equipments and improvement of health care. we must find local industry for medical equipments to face international competition. our studies reveal that we must have our medical equipments especially suture, our studies also reveal that local industry for medical equipment not present especially polyproplene suture which leads to increase import suture from out side and also decrease researches specialized for these reasons ${ }^{(17)}$.

\section{3- IMPORTANCE OF RESEARCH:}

The use of Polyproplene monofilament has increased greatly during recent years. Polyproplene suture compare to monofilament nylon, tie more secure knots and have a very low order of tissue reactivity. Because of the smoothness of polyproplene sutures, they slip through tissue easily and, because there is no tissue ingrowths, they may be removed easily when necessary $^{(3)}$.

A surgical suture is used to close the edges of a wound or incision and to repair damaged tissue. There are many kinds of sutures, with different properties suitable for various uses. Sutures can be divided into two main groups: absorbable and non-absorbable. An absorbable suture decomposes in the body. It degrades as a wound or incision heals. A nonabsorbable suture resists the body's attempt to dissolve it. Non-absorbable sutures may be removed by a surgeon after a surface incision has healed. 
Sutures are made from both man-made and natural materials. Natural suture materials include silk, linen, and catgut, prepared submucous coat of the sheep's (and , more recently, cow's) intestine, plain catgut is selected for fine suture and ligatures where rapid digestion is no disadvantage . Chromicized catgut has been treated to delay digestion in the tissues. ${ }^{(4)}$

Synthetic sutures are made from a variety of textiles such as nylon or polyester, formulated specifically for surgical use ${ }^{(10)}$.

Absorbable synthetic sutures are made from polyglycolic acid or other glycolide polymers. Most of the synthetic suture materials have proprietary names, such as Dexon and Vicryl.

The water-resistant material Goretex has been used for surgical sutures, and other sutures are made from thin metal wire Sutures are also classified according to their form. Some are monofilaments, that is, consisting of only one thread-like structure. Others consist of several filaments braided or twisted together. Surgeons choose which type of suture to use depending on the operation. A monofilament has what is called low tissue drag, meaning it passes smoothly through tissue. Braided or twisted sutures may have higher tissue drag, but are easier to knot and have greater knot strength. Braided sutures are usually coated to improve tissue drag. Other sutures may have a braided or twisted core within a smooth sleeve of extruded material. These are known as pseudo-monofilaments.

There is a multiplicity of techniques and materials for closing wounds. Any technique should avoid tension and there is no definite need to avoid dead space, although haemostasis is important. The hypoxia at the wound edge is the stimulus, through released chemoattractants, to macrophage function which in turn directs fibroblastic activity and angiogenesis the healing wound ${ }^{(6)}$.

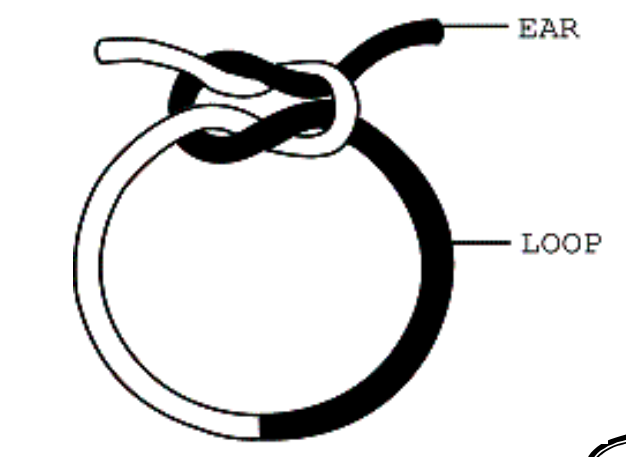

Figure(3):Components Of a Tied Suture( Square Knot ) 
As with other synthetic suture, knot security requires the standard surgical technique of square ties with additional throws as indicated by surgical circumstances and experience of the operator. ${ }^{(11)}$

\section{KNOT BREAKAGE}

When enough force is applied to the tied suture to result in breakage, the site of disruption of the suture is almost always the knot. The force necessary to break a knotted suture is lower than that required to break an untied suture made of the same material. The forces exerted on a tied suture are converted into shear forces by the knot configuration that break the knot. The percentage loss of tensile strength, as a result of tying a secure knot, is least with monofilament and multifilament steel. This relationship between the tensile strength of unknotted and knotted suture, which is designated knot efficiency, is described in the following equation:

KNOT EFFICIENCY $(\%)=$ Tensile strength of a knotted suture $\div$ Tensile strength of a knotted suture

Regardless of the type of suture material, the efficiency of the knot is enhanced with an increasing number of throws, although only up to a certain limit. The type of knot configuration that results in a secure knot that fails by breaking varies considerably with different suture material. The magnitude of force necessary to produce knot breakage is influenced by the configuration of the knotted suture loop, type of suture material, and the diameter of the suture. The tissue in which the suture is implanted also has considerable influence on the knot strength of suture. In the case of absorbable sutures, a progressive decline in knot breaking strength is noted after tissue implantation. In addition, the magnitude of knot breakage force is significantly influenced by the rate of application of forces to the "ears" of the knot. When a constant force is applied slowly to the knot "ears," the knot breakage force is significantly greater than that for knots in which the same constant force is applied rapidly to the "ears." The latter knot loading rate is often referred to as "the jerk at the end of the knot," especially when the knotted suture breaks ${ }^{(12)}$. 


\section{4-: THE METHODOLOGY OF RESEARCH:}

Depends On The Experimental Analytical Approach.

\section{5- OBJECTIVES OF RESEARCH:}

1-To study the effect Of Temperature In Melt Spinning Of Polypropylene that affect Properties of Suture .

2- To study the effect of Diameter Suture Polypropylene that affect Properties Suture .

\section{MATERIALS OF SUTURE USED IN RESEARCH}

\section{6-1:SPECIFICATION OF POLYPROPYLENE :}

\section{1-DENSITY 0.9 GRAM/CM3}

According To American Standard Specification D-1505

2-MFI 3 GRAM/10MIN

According To American Standard Specification D-1238

\section{6-2:SPECIFICATION OF MASTER BATCH :}

Specification Of Master Batch Is $0.5 \%$ And Colour Of Suture Polypropylene Is Blue .According To Unit Stats Pharmacopoeia, European Pharmacopoeia And British Pharmacopoeia ${ }^{(7),(8),(9)}$.

\section{7-FACTORS EXAMINED THROUGH THE RESEARCH}

\section{7-1:UNCHANGEABLE SPECIFICATIONS:}

7-1-1:Polypropylene Material.

7-1-2:Machine Row Of Melt Spinning

7-1-3:Speed Of Winding.

7-1-4:Material Master Batch.

7-1-5:Stretching 1:5.

\section{7-2:CHANGEABLE SPECIFICATIONS:}

\section{7-2-1:TEMPERATURE.}

A-Temperature Of Zone $\left(240-250-250-260-265^{\circ} \mathrm{C}\right)$.

B- Temperature Of Zone (260-270-270-280-285 $\left.{ }^{\circ} \mathrm{C}\right)$. 
C- Temperature Of Zone( 280-290-290-300-305 ${ }^{0}$ C)

\section{7-2-2: DIAMETER:}

A-1.5 Metric Size.

B-2 Metric Size.

C-2.5 Metric Size.

\section{8-RESULTS \& DISCUSSION}

The tests of tensile strength and elongation by knot and with knot on samples of poly propylene sutures which made in laboratory with the temperature of $20 \pm 1$ and Relative Humidity of $65 \pm 2$ for obtaining suture with special properties suitable for economic level and end use. The results of these measurements in the following tables:

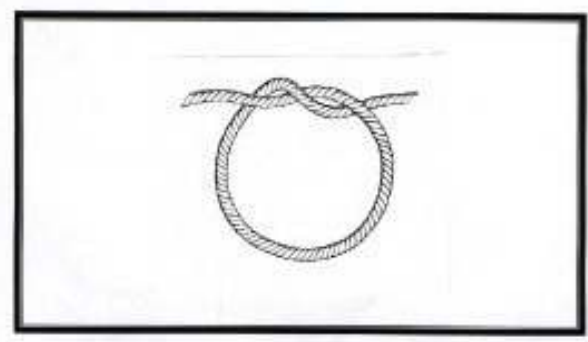

Figure(4): Shows Suture with Knot used for Tensile Strength And Elongation .

Table(1):Results of Polypropylene Sutures At Temperature $\left(240: 265^{\circ} \mathrm{c}\right)$.

\begin{tabular}{||c|c|c|c|c|c||}
\hline N & $\begin{array}{c}\text { Code } \\
\text { Of } \\
\text { Sample }\end{array}$ & $\begin{array}{c}\text { Tensile } \\
\text { Strength } \\
\text { Without } \\
\text { knot }(\text { Kg) }\end{array}$ & $\begin{array}{c}\text { Elongation } \\
\text { Without } \\
\text { knot }(\mathbf{m m})\end{array}$ & $\begin{array}{c}\text { Tensile } \\
\text { Strength } \\
\text { With Knot } \\
(\text { Kg) }\end{array}$ & $\begin{array}{c}\text { Elongation } \\
\text { With Knot } \\
(\mathbf{m m})\end{array}$ \\
\hline \hline 1 & H-28 & $\mathbf{1 . 1 8 5 8}$ & $\mathbf{5 2 . 4 7 2}$ & $\mathbf{1 . 0 3 6 4}$ & $\mathbf{3 4 . 0 3 2}$ \\
\hline 2 & H-29 & 1.0686 & 48.6964 & $\mathbf{0 . 9 5 3}$ & $\mathbf{3 3 . 3 2}$ \\
\hline 3 & H-30 & $\mathbf{0 . 9 6 3}$ & 46.568 & $\mathbf{0 . 8 9 1 6}$ & $\mathbf{3 4 . 1 8 8 8}$ \\
\hline
\end{tabular}

Table(2):Results of Polypropylene Sutures At Temperature $\left(260: 285^{0} \mathrm{c}\right)$.

\begin{tabular}{|c|c|c|c|c|c||}
\hline N & $\begin{array}{c}\text { Code Of } \\
\text { Sample }\end{array}$ & $\begin{array}{c}\text { Tensile } \\
\text { Strength } \\
\text { Without } \\
\text { knot (Kg) }\end{array}$ & $\begin{array}{c}\text { Elongation } \\
\text { Without } \\
\text { knot }(\mathrm{mm})\end{array}$ & $\begin{array}{c}\text { Tensile } \\
\text { Strength } \\
\text { With Knot } \\
(\text { Kg) }\end{array}$ & $\begin{array}{c}\text { Elongation } \\
\text { With Knot } \\
(\mathrm{mm})\end{array}$ \\
\hline 1 & $\mathbf{E - 3 7}$ & $\mathbf{1 . 2 3 0 2}$ & $\mathbf{5 8 . 1 8}$ & $\mathbf{1 . 1 7}$ & $\mathbf{3 5 . 9}$ \\
\hline 2 & $\mathbf{E - 3 8}$ & $\mathbf{0 . 9 6 3 4}$ & $\mathbf{7 6 . 6 8}$ & $\mathbf{0 . 8 1 6 8}$ & $\mathbf{4 1 . 9 4}$ \\
\hline 3 & $\mathbf{E - 3 9}$ & $\mathbf{0 . 9 0 5 2}$ & $\mathbf{5 4 . 3 4 6}$ & $\mathbf{0 . 8 0 8 4}$ & $\mathbf{3 6 . 9 2 6}$ \\
\hline
\end{tabular}


Table(3):Results of Polypropylene Sutures At Temperature $\left(280: 305^{0} \mathrm{c}\right)$.

\begin{tabular}{||c|c|c|c|c|c||}
\hline N & $\begin{array}{c}\text { Code Of } \\
\text { Sample }\end{array}$ & $\begin{array}{c}\text { Tensile } \\
\text { Strength } \\
\text { Without } \\
\text { knot (Kg) }\end{array}$ & $\begin{array}{c}\text { Elongation } \\
\text { Without } \\
\text { knot }(\mathbf{m m})\end{array}$ & $\begin{array}{c}\text { Tensile } \\
\text { Strength } \\
\text { With Knot } \\
(\text { Kg) }\end{array}$ & $\begin{array}{c}\text { Elongation } \\
\text { With Knot } \\
(\mathbf{m m})\end{array}$ \\
\hline 1 & $\mathrm{~A}-46$ & 1.836 & 46.956 & 1.565 & $\mathbf{3 2 . 0 4 3 6}$ \\
\hline 2 & $\mathrm{~A}-47$ & 1.8584 & 43.8152 & 1.541 & $\mathbf{3 1 . 0 7 8}$ \\
\hline 3 & $\mathrm{~A}-48$ & 1.7586 & 44.9538 & 1.5192 & $\mathbf{2 9 . 2 0 1 6}$ \\
\hline
\end{tabular}

\section{8-1: Tensile Strength With Knot And Without Knot}

\section{8-1-1: Relationship Between Temperature And Tensile Strength With Knot And Without Knot At 2.5 Metric Size.}

Table(4): Relationship Between Temperature And Tensile Strength With Knot And Without Knot At 2.5 Metric Size.

\begin{tabular}{||c|c|c|c||}
\hline $\mathbf{N}$ & $\begin{array}{c}\text { Code Of } \\
\text { Sample }\end{array}$ & $\begin{array}{c}\text { Tensile Strength } \\
\text { Without knot (Kg) } \\
\Delta\end{array}$ & $\begin{array}{c}\text { Tensile Strength With } \\
\text { Knot (Kg) }\end{array}$ \\
\hline 1 & H-28 & 1.1858 & 1.0364 \\
\hline 2 & E-37 & 1.2302 & 1.17 \\
\hline 3 & A-46 & 1.836 & 1.565 \\
\hline
\end{tabular}

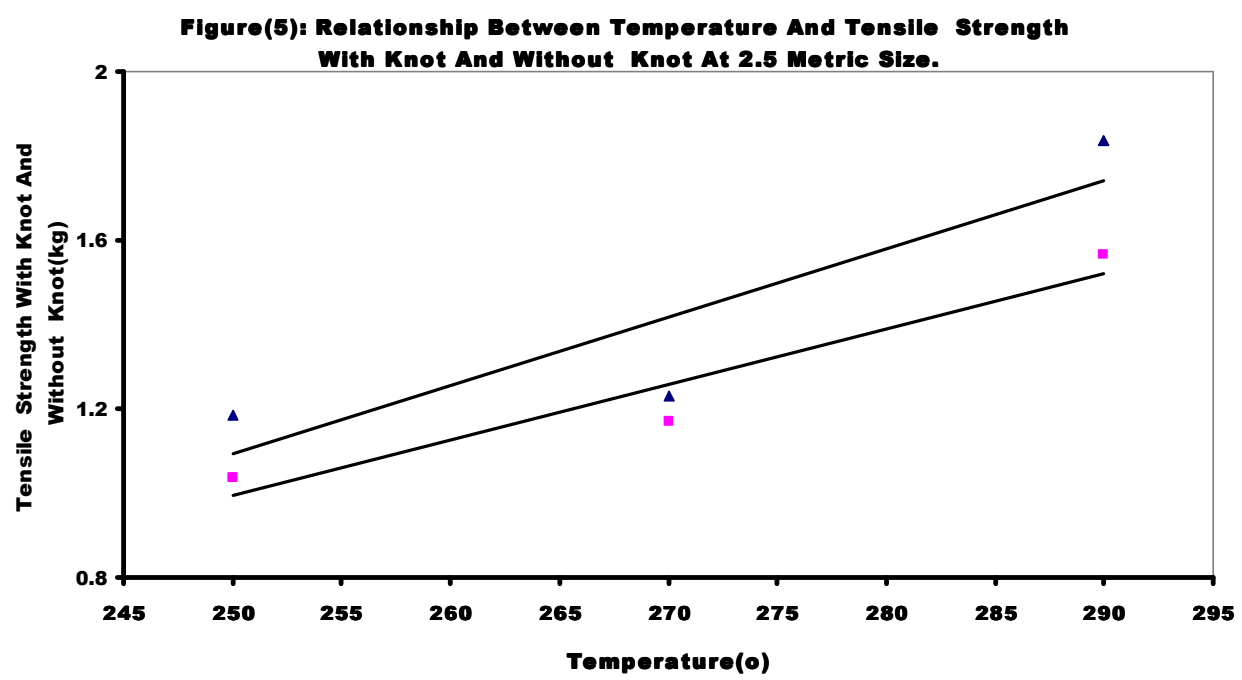

Figure(5) shows Relationship Between Temperature And Tensile Strength Without Knot At 2.5 Metric Size. Represented the straight line equation of samples(H28-E37-A46) $\boldsymbol{\Delta}$ Tensile strength without knot $\mathrm{y}=2.97+0.02 \mathrm{x} \quad \mathrm{r}=0.9$ 
as the temperature increases. It's found that tensile strength without knot increases also.

It's also found that the correlation factor is $\mathrm{r}=0.9$ which indicates that there is a strong proportional relation between temperature and tensile strength without knot.

And also Figure(5) shows Relationship Between Temperature And Tensile Strength With Knot At 2.5 Metric Size.

Represented the straight line equation of samples (H28-E37-A46)

Tensile strength with knot $\quad \mathrm{y}=2.31+0.01 \mathrm{x} \quad \mathrm{r}=0.9$

as the temperature increases. It's found that tensile strength with knot increases also. It's also found that the correlation factor is $\mathrm{r}=0.9$ which indicates that there is a strong proportional relation between temperature and tensile strength with knot. As a result from increase temperature leads to increase flexibility fibers leads to increase in the tensile strength of poly propylene suture with knot.

\section{8-1-2: Relationship Between Temperature And Tensile Strength With Knot And Without Knot At 2 Metric Size.}

Table(5): Relationship Between Temperature And Tensile Strength With Knot And Without Knot At 2 Metric Size.

\begin{tabular}{|c|c|c|c||}
\hline N & $\begin{array}{c}\text { Code Of } \\
\text { Sample }\end{array}$ & $\begin{array}{c}\text { Tensile Strength } \\
\text { Without knot }(\mathrm{Kg})\end{array}$ & $\begin{array}{c}\text { Tensile Strength With Knot } \\
(\text { Kg) }\end{array}$ \\
\hline 1 & H-29 & 1.0686 & 0.953 \\
\hline 2 & E-38 & 0.9634 & 0.8168 \\
\hline 3 & $\mathbf{A - 4 7}$ & 1.8584 & 1.541 \\
\hline
\end{tabular}




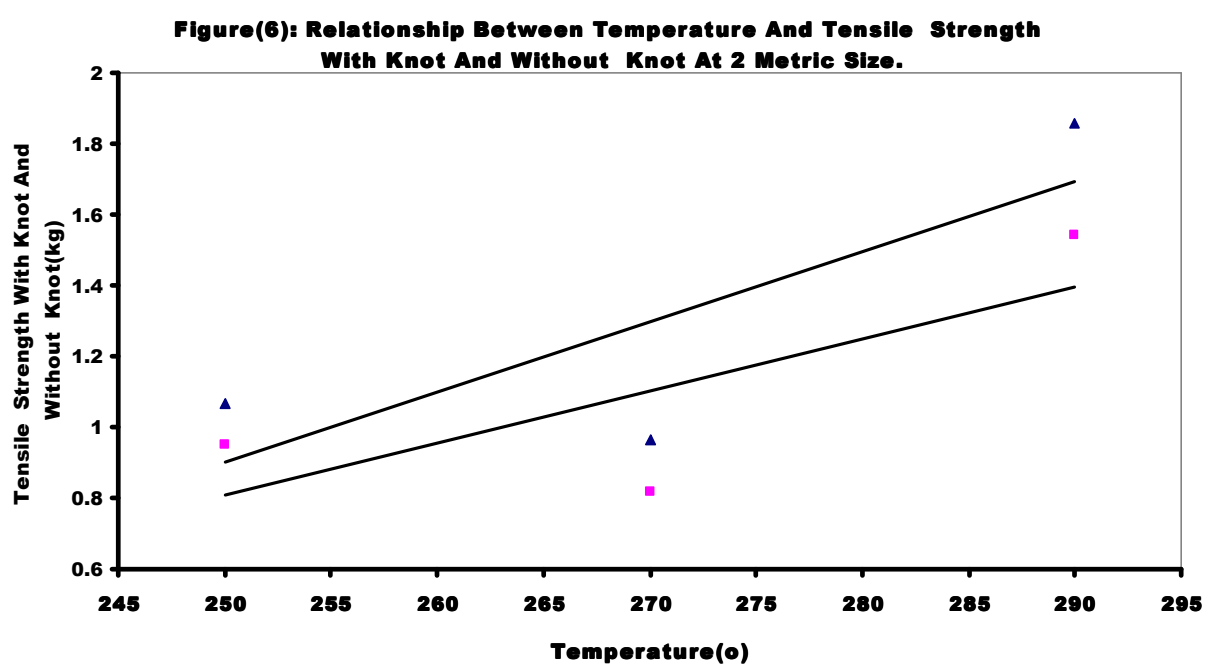

Figure(6): shows Relationship Between Temperature And Tensile Strength Without Knot At 2 Metric Size.

Represented the straight line equation of samples (H29-E38-A47)

Tensile strength without knot $y=-4.03+0.02 x \quad r=0.8$

as the temperature increases. It's found that tensile strength without knot increases also. It's also found that the correlation factor is $\mathrm{r}=0.8$ which indicates that there is a strong proportional relation between temperature and tensile strength without knot.

And also Figure(6) shows Relationship Between Temperature And Tensile Strength With Knot At 2 Metric Size.

Represented the straight line equation of samples (H29-E38-A47)

Tensile strength with knot $\mathrm{y}=-2.87+0.01 \mathrm{x} \quad \mathrm{r}=0.8$

as the temperature increases. It's found that tensile strength with knot increases also. It's also found that the correlation factor is $\mathrm{r}=0.8$ which indicates that there is a strong proportional relation between temperature and tensile strength with knot. As a result from increase temperature leads to increase flexibility fibers leads to increase in the tensile strength with knot. 


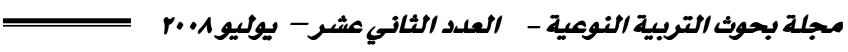

\section{8-1-3: Relationship Between Temperature And Tensile Strength With Knot And Without Knot At 1.5 Metric Size.}

Table(6): Relationship Between Temperature And Tensile Strength With Knot And Without Knot At 1.5 Metric Size.

\begin{tabular}{||c|c|c|c||}
\hline $\mathrm{N}$ & $\begin{array}{c}\text { Code Of } \\
\text { Sample }\end{array}$ & $\begin{array}{c}\text { Tensile Strength } \\
\text { Without knot (Kg) }\end{array}$ & $\begin{array}{c}\text { Tensile Strength } \\
\text { With Knot (Kg) }\end{array}$ \\
\hline 1 & $\mathbf{H}-30$ & $\mathbf{0 . 9 6 3}$ & $\mathbf{0 . 8 9 1 6}$ \\
\hline 2 & $\mathrm{E}-39$ & $\mathbf{0 . 9 0 5 2}$ & $\mathbf{0 . 8 0 8 4}$ \\
\hline 3 & $\mathrm{~A}-48$ & 1.7586 & 1.5192 \\
\hline
\end{tabular}

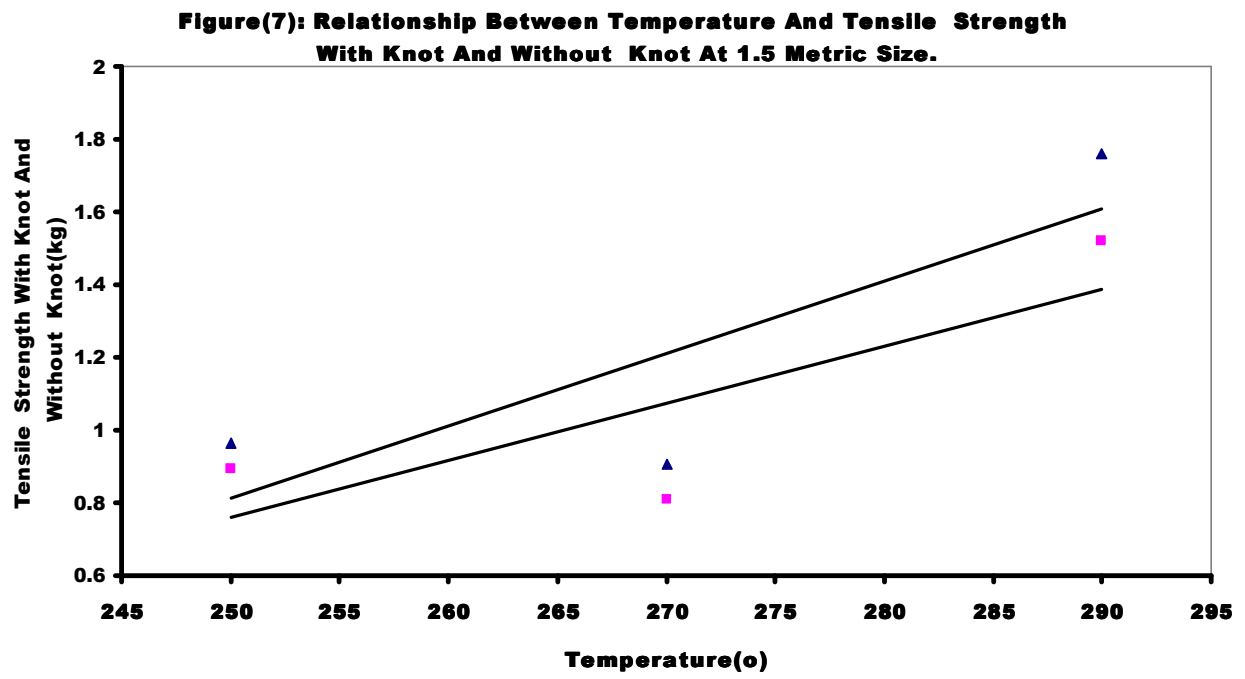

Figure(7) shows Relationship Between Temperature And Tensile Strength Without Knot At 1.5 Metric Size.

Represented the straight line equation of samples (H30-E39-A48)

Tensile strength without knot $\mathrm{y}=-4.16+0.02 \mathrm{x} \quad \mathrm{r}=0.8$

as the temperature increases. It's found that tensile strength without knot increases also. It's also found that the correlation factor is $\mathrm{r}=0.8$ which indicates that there is a strong proportional relation between temperature and tensile strength without knot.

And also Figure(7) shows Relationship Between Temperature And Tensile Strength With Knot At 1.5 Metric Size. 
Represented the straight line equation of samples (H30-E39-A48)

Tensile strength with knot $\mathrm{y}=-3.16+0.02 \mathrm{x} \quad \mathrm{r}=0.8$

as the temperature increases. It's found that tensile strength with knot increases also. It's also found that the correlation factor is $r=0.8$ which indicates that there is a strong proportional relation between temperature and tensile strength with knot. As a result from increase temperature leads to increase flexibility fibers leads to increase in the tensile strength of poly propylene suture with knot.

\section{8-1-4: Relationship Between Diameter And Tensile Strength With Knot And Without Knot At Temperature (240:265 0C).}

Table(7): Relationship Between Diameter And Tensile Strength With Knot And Without Knot At Temperature $\left(240: 265^{\circ} \mathrm{C}\right)$.

\begin{tabular}{|c|c|c|c||}
\hline N & $\begin{array}{c}\text { Code Of } \\
\text { Sample }\end{array}$ & $\begin{array}{c}\text { Tensile Strength } \\
\text { Without knot (Kg) } \\
\Delta\end{array}$ & $\begin{array}{c}\text { Tensile Strength } \\
\text { With Knot (Kg) }\end{array}$ \\
\hline 1 & H-28 & 1.1858 & 1.0364 \\
\hline 2 & H-29 & 1.0686 & $\mathbf{0 . 9 5 3}$ \\
\hline 3 & H-30 & $\mathbf{0 . 9 6 3}$ & $\mathbf{0 . 8 9 1 6}$ \\
\hline
\end{tabular}

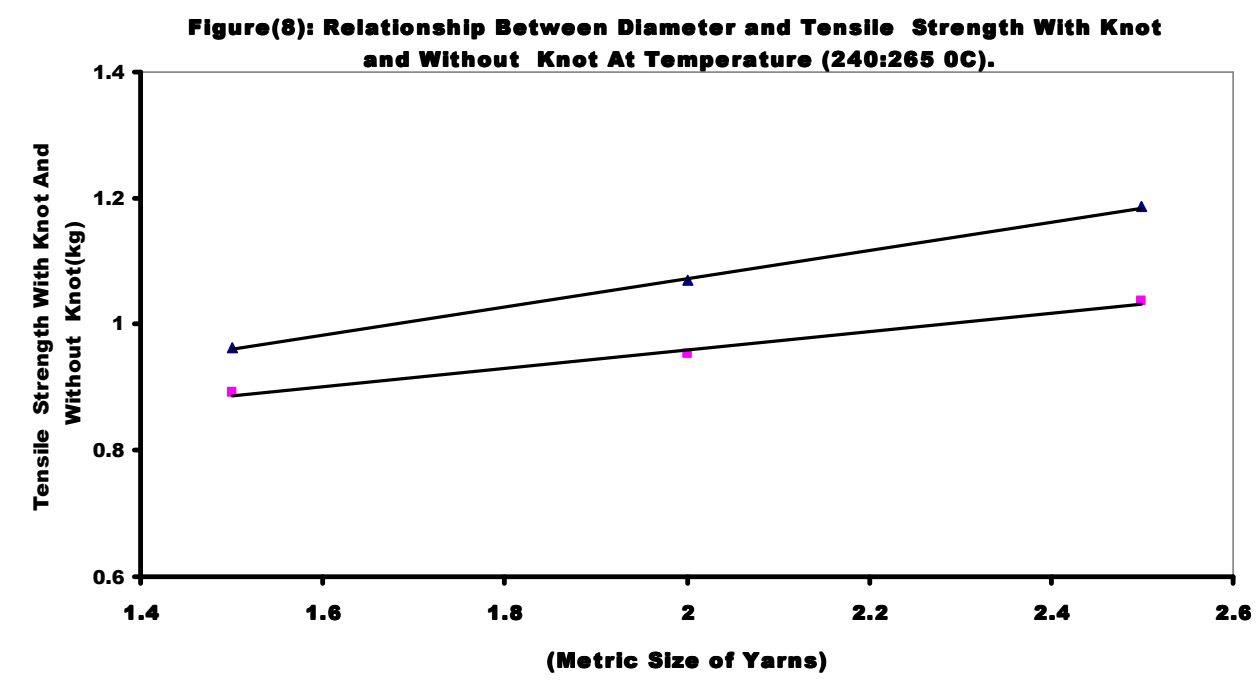

Figure(8) shows Relationship Between Diameter And Tensile Strength Without Knot At Temperature $\left(240: 265{ }^{\circ} \mathrm{C}\right)$.

Represented the straight line equation of samples (H28- H29- H30)

Tensile strength without knot $\mathrm{y}=0.63+0.22 \mathrm{x} \quad \mathrm{r}=0.9$ 
as the Diameter increases. It's found that tensile strength without knot increases also.

It's also found that the correlation factor is $r=0.9$ which indicates that there is a strong proportional relation between Diameter and tensile strength without knot.

And also Figure(8) shows Relationship Between Diameter And Tensile Strength With Knot At Temperature $\left(240: 265{ }^{\circ} \mathrm{C}\right)$.

Represented the straight line equation of samples (H28- H29- H30)

Tensile strength with knot $\quad \mathrm{y}=2.31+0.01 \mathrm{x} \quad \mathrm{r}=0.9$

as the Diameter increases. It's found that tensile strength with knot increases also. It's also found that the correlation factor is $\mathrm{r}=0.9$ which indicates that there is a strong proportional relation between temperature and tensile strength with knot. As a result from in the sample of suture 2.5 metric size gives greatest tensile strength without knot and diameter of 1.5 metric size gives the least tensile strength without knot and these result from increase of polypropylene suture cross section.

\section{8-1-5: Relationship Between Diameter And Tensile Strength With Knot And Without Knot At Temperature (260:285 0C).}

Table(8): Relationship Between Diameter And Tensile Strength With Knot And Without Knot At Temperature (260:2850C).

\begin{tabular}{|c|c|c|c||}
\hline $\mathbf{N}$ & $\begin{array}{c}\text { Code Of } \\
\text { Sample }\end{array}$ & $\begin{array}{c}\text { Tensile Strength } \\
\text { Without knot (Kg) }\end{array}$ & $\begin{array}{c}\text { Tensile Strength } \\
\text { With Knot (Kg) } \\
\mathbf{B}\end{array}$ \\
\hline 1 & E-37 & 1.2302 & 1.17 \\
\hline 2 & E-38 & $\mathbf{0 . 9 6 3 4}$ & $\mathbf{0 . 8 1 6 8}$ \\
\hline 3 & E-39 & $\mathbf{0 . 9 0 5 2}$ & $\mathbf{0 . 8 0 8 4}$ \\
\hline
\end{tabular}




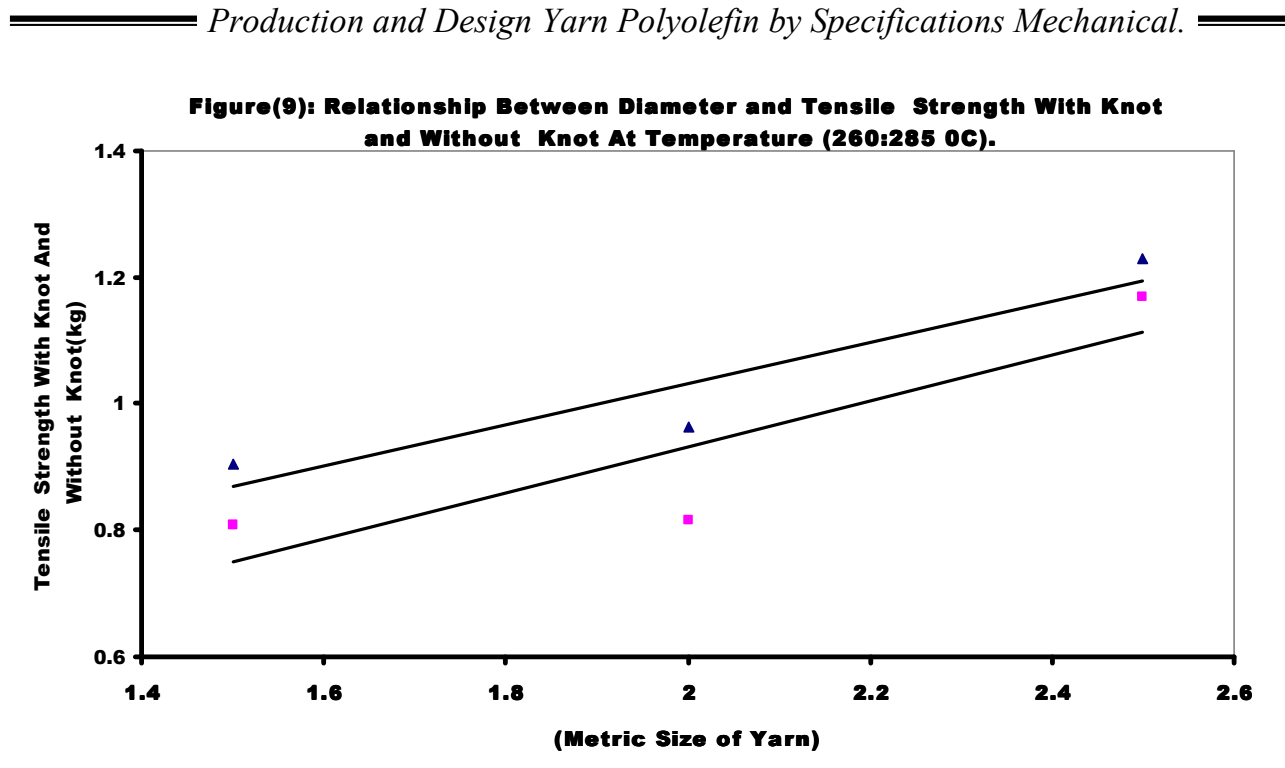

Figure(9) shows Relationship Between Diameter And Tensile Strength Without Knot At Temperature $\left(260: 285^{\circ} \mathrm{C}\right)$.

Represented the straight line equation of samples (E37- E38- E39)

Tensile strength without knot $\mathrm{y}=0.38+0.33 \mathrm{x} \quad \mathrm{r}=0.9$

as the Diameter increases. It's found that tensile strength without knot increases also.

It's also found that the correlation factor is $\mathrm{r}=0.9$ which indicates that there is a strong proportional relation between Diameter and tensile strength without knot.

And also Figure(9) shows Relationship Between Diameter And Tensile Strength With Knot At Temperature $\left(260: 285^{\circ} \mathrm{C}\right)$.

Represented the straight line equation of samples (E37- E38-E39)

Tensile strength with knot $\quad \mathrm{y}=0.31+0.54 \mathrm{x} \quad \mathrm{r}=0.9$

as the Diameter increases. It's found that tensile strength with knot increases also.

It's also found that the correlation factor is $r=0.9$ which indicates that there is a strong proportional relation between temperature and tensile strength with knot. 
As a result from in the sample of suture 2.5 metric size gives greatest tensile strength without knot and diameter of 1.5 metric size gives the least tensile strength without knot and these result from increase cross section.

\section{8-1-6: Relationship Between Diameter And Tensile Strength With Knot And Without Knot At Temperature (280:305 0C).}

Table(9): Relationship Between Diameter And Tensile Strength With Knot And Without Knot At Temperature $\left(280: 305{ }^{\circ} \mathrm{C}\right)$.

\begin{tabular}{|c|c|c|c||}
\hline $\mathrm{N}$ & $\begin{array}{c}\text { Code Of } \\
\text { Sample }\end{array}$ & $\begin{array}{c}\text { Tensile Strength } \\
\text { Without knot }(\mathrm{Kg})\end{array}$ & $\begin{array}{c}\text { Tensile Strength } \\
\text { With Knot }(\mathrm{Kg})\end{array}$ \\
\hline 1 & $\mathrm{~A}-46$ & 1.836 & 1.565 \\
\hline 2 & $\mathrm{~A}-47$ & 1.8584 & 1.541 \\
\hline 3 & $\mathrm{~A}-48$ & 1.7586 & 1.5192 \\
\hline
\end{tabular}

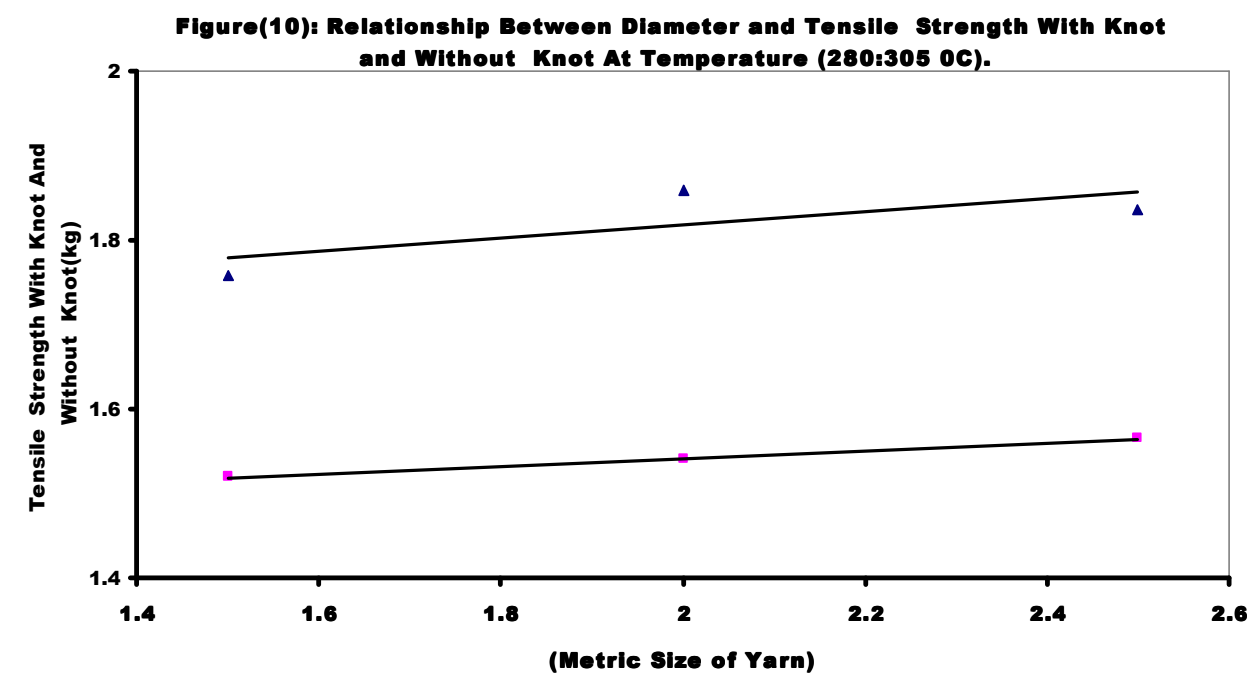

Figure(10) shows Relationship Between Diameter And Tensile Strength Without Knot At Temperature $\left(280: 305{ }^{\circ} \mathrm{C}\right)$.

Represented the straight line equation of samples (A46- A47- A48)

Tensile strength without knot $y=1.66-0.08 x \quad r=0.7$

as the Diameter increases. It's found that tensile strength without knot increases also. 
It's also found that the correlation factor is $\mathrm{r}=0.7$ which indicates that there is a strong proportional relation between Diameter and tensile strength without knot. Represented the straight line equation of samples (A46A47- A48)

Tensile strength with knot $y=1.45-0.05 x \quad r=0.9$

as the Diameter increases. It's found that tensile strength with knot increases also.

It's also found that the correlation factor is $r=0.9$ which indicates that there is a strong proportional relation between temperature and tensile strength with knot.

As a result from in the sample of suture 2.5 metric size gives greatest tensile strength without knot and diameter of 1.5 metric size gives the least tensile strength without knot and these result from increase cross section.

\section{8-1-7: Comparison Between Diameter And Tensile Strength With Knot And Without Knot .}

Table(10): Comparison Between Diameter And Tensile Strength With Knot and Without Knot.

\begin{tabular}{|c|c|c|c|}
\hline $\mathbf{N}$ & $\begin{array}{l}\text { Code Of } \\
\text { Sample }\end{array}$ & $\begin{array}{c}\text { Tensile Strength } \\
\text { Without knot (Kg) }\end{array}$ & $\begin{array}{l}\text { Tensile Strength With Knot } \\
\text { (Kg) }\end{array}$ \\
\hline 1 & H-28 & 1.1858 & 1.0364 \\
\hline 2 & H-29 & 1.0686 & 0.953 \\
\hline 3 & H-30 & 0.963 & 0.8916 \\
\hline 4 & E-37 & 1.2302 & 1.17 \\
\hline 5 & E-38 & 0.9634 & 0.8168 \\
\hline 6 & E-39 & 0.9052 & 0.8084 \\
\hline 7 & A-46 & 1.836 & 1.565 \\
\hline 8 & A-47 & 1.8584 & 1.541 \\
\hline 9 & A-48 & 1.7586 & 1.5192 \\
\hline
\end{tabular}

Figure(11) shows Comparison Between Diameter And Tensile Strength Without Knot . The results show that greatest level of tensile strength without knot achieved at A-47 which measured $1.86 \mathrm{~kg}$ at temperature (260-270-270-280-285 $\mathrm{C}$ ) and Diameter 2 metric size. 
The second sample of tensile strength without knot achieved atA-46 which measured $1.83 \mathrm{~kg}$ at temperature $\left(240-250-250-260-265^{\circ} \mathrm{C}\right)$ and diameter 2.5 metric size.

The third sample of tensile strength without knot achieved at A-48 which measured $1.76 \mathrm{~kg}$ at temperature $\left(280-290-290-300-305^{\circ} \mathrm{C}\right)$ and diameter 1.5 metric size.

And also Figure(11) shows Relationship Between Diameter And Tensile Strength With Knot.

Figure(11): Comparison Between Diameter And Tensile Strength With Knot And Without Knot .

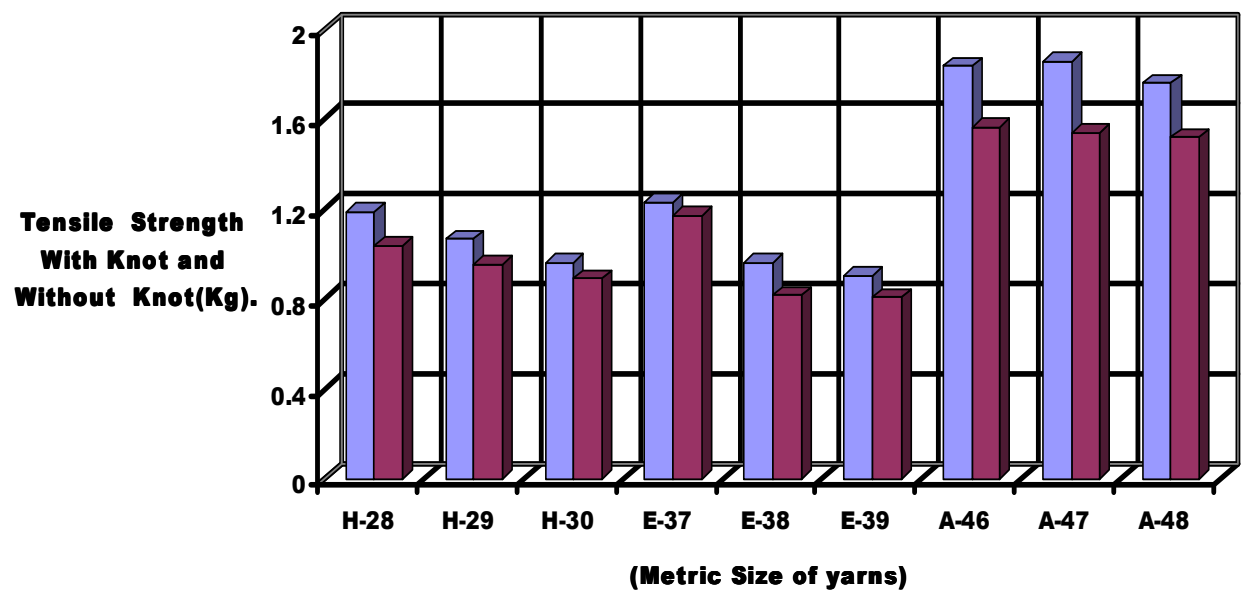

The results show that greatest level of tensile strength with knot achieved at A-46 which measured $1.57 \mathrm{~kg}$ at temperature (240-250-250$260-265^{\circ} \mathrm{C}$ ) and Diameter 2.5 metric size.

The second sample of tensile strength with knot achieved at A-47 which measured $1.54 \mathrm{~kg}$ at temperature $\left(260-270-270-280-285^{\circ} \mathrm{C}\right)$ and diameter 2 metric size.

The third sample of tensile strength with knot achieved at A-48 which measured $1.52 \mathrm{~kg}$ at temperature $\left(280-290-290-300-305^{\circ} \mathrm{C}\right)$ and diameter 1.5 metric size. 


\section{8-2: Elongation With Knot And Without Knot.}

\section{8-2-1: Relationship Between Temperature And Elongation With Knot And Without Knot At 2.5 Metric Size.}

Table (11): Relationship Between Temperature And Elongation With Knot And Without Knot At 2.5 Metric Size.

\begin{tabular}{|c|c|c|c||}
\hline N & $\begin{array}{c}\text { Code Of } \\
\text { Sample }\end{array}$ & $\begin{array}{c}\text { Elongation Without } \\
\text { knot }(\mathrm{mm}) \\
\Delta\end{array}$ & $\begin{array}{c}\text { Elongation With } \\
\text { Knot (mm) }\end{array}$ \\
\hline 1 & H-28 & 52.472 & 34.032 \\
\hline 2 & E-37 & 58.18 & 35.9 \\
\hline 3 & A-46 & 46.956 & 32.0436 \\
\hline
\end{tabular}

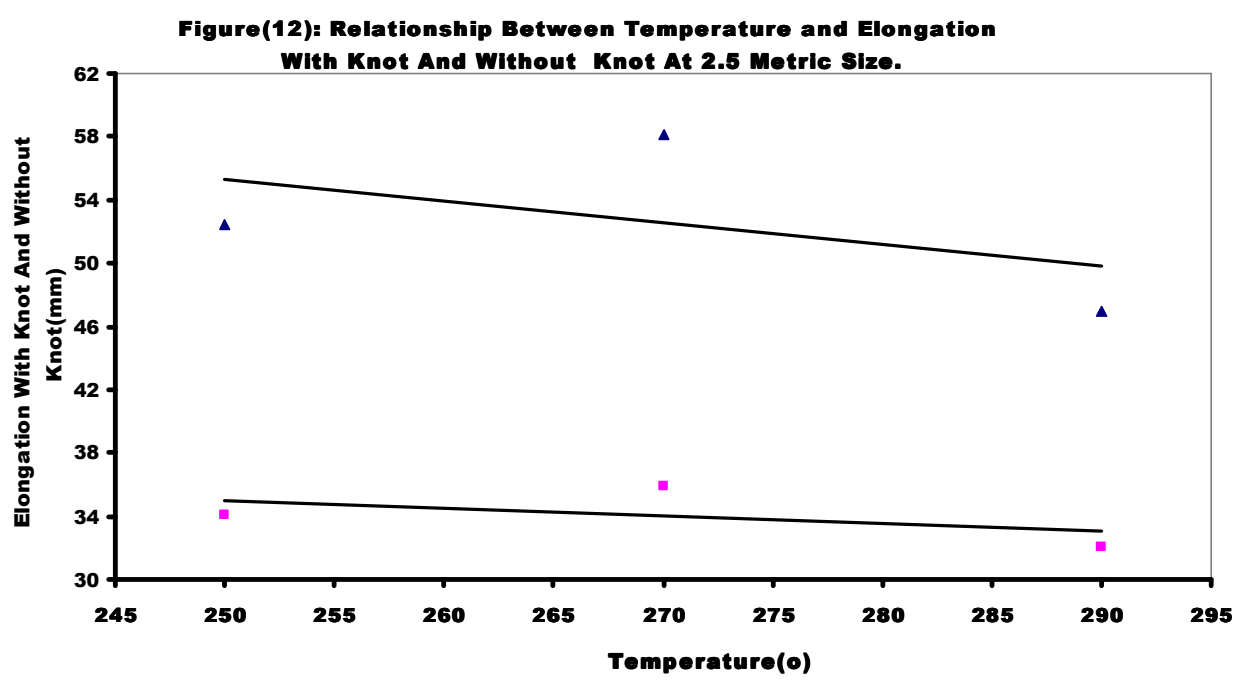

Figure(12) shows Relationship Between Temperature And Elongation Without Knot At 2.5 Metric Size.

Represented the straight line equation of samples (H28-E37-A46)

Elongation without knot $\mathrm{y}=89.77-0.14 \mathrm{x} \quad \mathrm{r}=-0.5$

as the temperature decreases. It's found that Elongation without knot increases. 
It's also found that the correlation factor is $\mathrm{r}=-0.5$ which indicates that there is a an inverse relation between temperature and Elongation without knot.

And also Figure(12) shows Relationship Between Temperature And Elongation With Knot At 2.5 Metric Size.

Represented the straight line equation of samples (H28-E37-A46)

Elongation with knot $\quad \mathrm{y}=47.42-0.05 x \quad r=-0.5$

as the temperature increases. It's found that Elongation with knot increases also. It's also found that the correlation factor is $\mathrm{r}=-0.5$ which indicates that there is an inverse relation between temperature and Elongation with knot.

As a result from increase temperature leads to decrease elongation of poly propylene suture with knot.

When temperature of poly propylene suture increase leads to decrease elongation without knot as a result of change in passage of polypropylene material in screw melt spinning. of

When temperature decrease with increase passage of poly propylene material in screw at 2.5 METRIC SIZE diameter leads to that poly propylene suture not reached to the demanding temperature so leads to decrease elongation without knot .

When passage of poly propylene material in screw decrease at 1.5 METRIC SIZE

Leads to reached to the demanding temperature so leads to decrease elongation without knot .

\section{8-2-2: Relationship Between Temperature And Elongation With Knot And Without Knot At 2 Metric Size.}

Table(12): Relationship Between Temperature And Elongation With Knot And Without Knot At 2 Metric Size.

\begin{tabular}{||c|c|c|c||}
\hline \hline N & Code Of Sample & $\begin{array}{c}\text { Elongation Without } \\
\text { knot }(\mathbf{m m})\end{array}$ & $\begin{array}{c}\text { Elongation With } \\
\text { Knot }(\mathbf{m m})\end{array}$ \\
\hline 1 & $\mathbf{H}-29$ & 48.6964 & 33.32 \\
\hline 2 & E-38 & 76.68 & 41.94 \\
\hline 3 & A-47 & 43.8152 & 31.078 \\
\hline
\end{tabular}




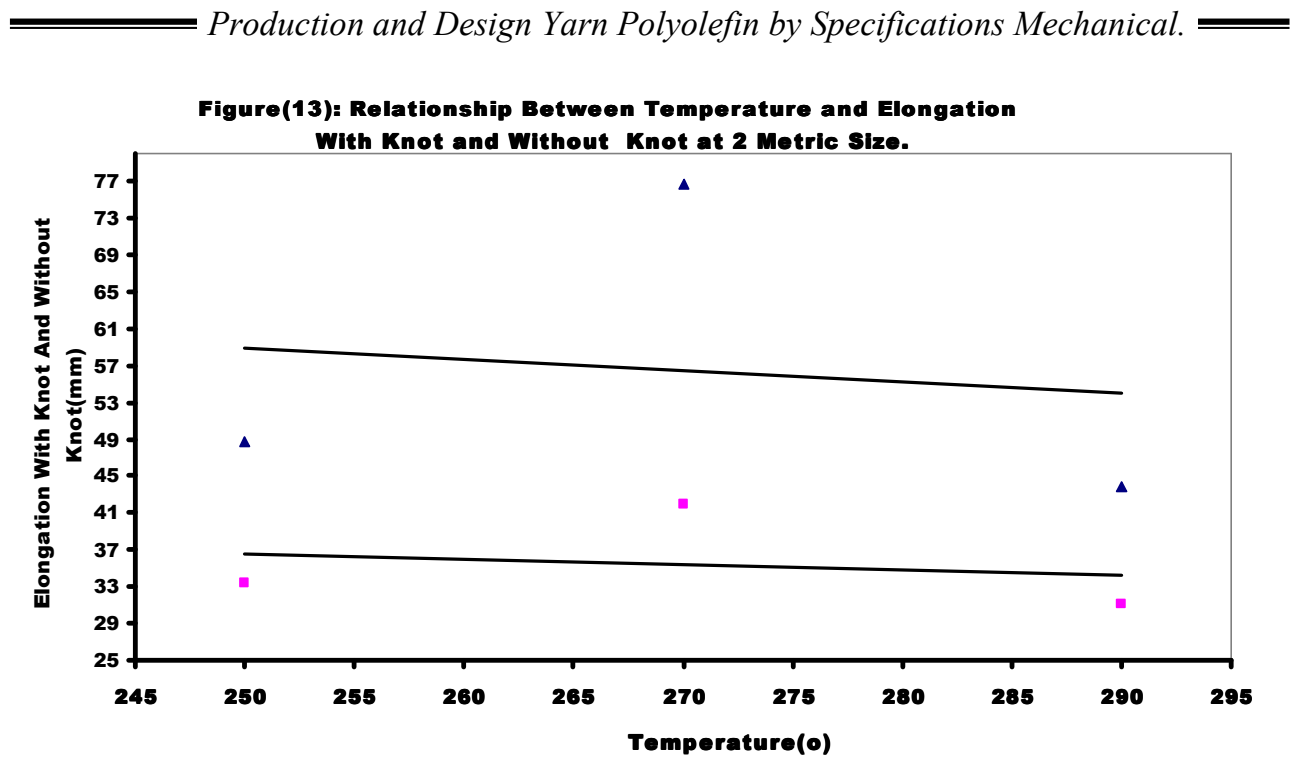

Figure(13) shows Relationship Between Temperature And Elongation Without Knot At 2 Metric Size.

Represented the straight line equation of samples(H29-E38-A47)

Elongation without knot $y=89.35-0.12 x \quad r=-0.1$

as the temperature decreases. It's found that Elongation without knot increases. The results show that greatest level of Elongation without knot achieved at E-38 which measured $76.68 \mathrm{~mm}$ at the temperature(260:285 $\left.{ }^{0} \mathrm{C}\right)$. The Least level of Elongation without knot achieved at A-47 measured 43.82 at the temperature $\left(280: 305{ }^{0} \mathrm{C}\right)$.

It's also found that the correlation factor is $r=-0.1$ which indicates that there is a an inverse relation between temperature and Elongation without knot.

And also Figure(13) shows Relationship Between Temperature And Elongation With Knot At 2 Metric Size.

Represented the straight line equation of samples (H29-E38-A47)

Elongation with knot $\mathrm{y}=50.58-0.06 \mathrm{x} \quad \mathrm{r}=-0.2$

as the temperature increases. It's found that Elongation with knot increases also. 
It's also found that the correlation factor is $\mathrm{r}=-0.2$ which indicates that there is an inverse relation between temperature and Elongation with knot.

As a result from increase temperature leads to decrease elongation of poly propylene suture with knot.

When temperature of poly propylene suture increase leads to decrease elongation without knot as a result of change in passage of polypropylene material in screw melt spinning. of

When temperature decrease with increase passage of poly propylene material in screw at 2.5 METRIC SIZE diameter leads to that poly propylene suture not reached to the demanding temperature so leads to decrease elongation without knot .

When passage of poly propylene material in screw decrease at 1.5 METRIC SIZE

Leads to reached to the demanding temperature so leads to decrease elongation without knot .

\section{8-2-3: Relationship Between Temperature And Elongation With Knot And Without Knot At 1.5 Metric Size.}

Table(13): Relationship Between Temperature And Elongation With Knot And Without Knot At 1.5 Metric Size.

\begin{tabular}{|c|c|c|c||}
\hline $\mathrm{N}$ & $\begin{array}{c}\text { Code Of } \\
\text { Sample }\end{array}$ & $\begin{array}{c}\text { Elongation Without } \\
\text { knot }(\mathrm{mm}) \\
\boldsymbol{A}\end{array}$ & $\begin{array}{c}\text { Elongation With } \\
\text { Knot }(\mathbf{m m})\end{array}$ \\
\hline 1 & $\mathrm{H}-30$ & 46.568 & 34.1888 \\
\hline 2 & $\mathrm{E}-39$ & 54.346 & 36.926 \\
\hline 3 & $\mathrm{~A}-48$ & 44.9538 & 29.2016 \\
\hline
\end{tabular}




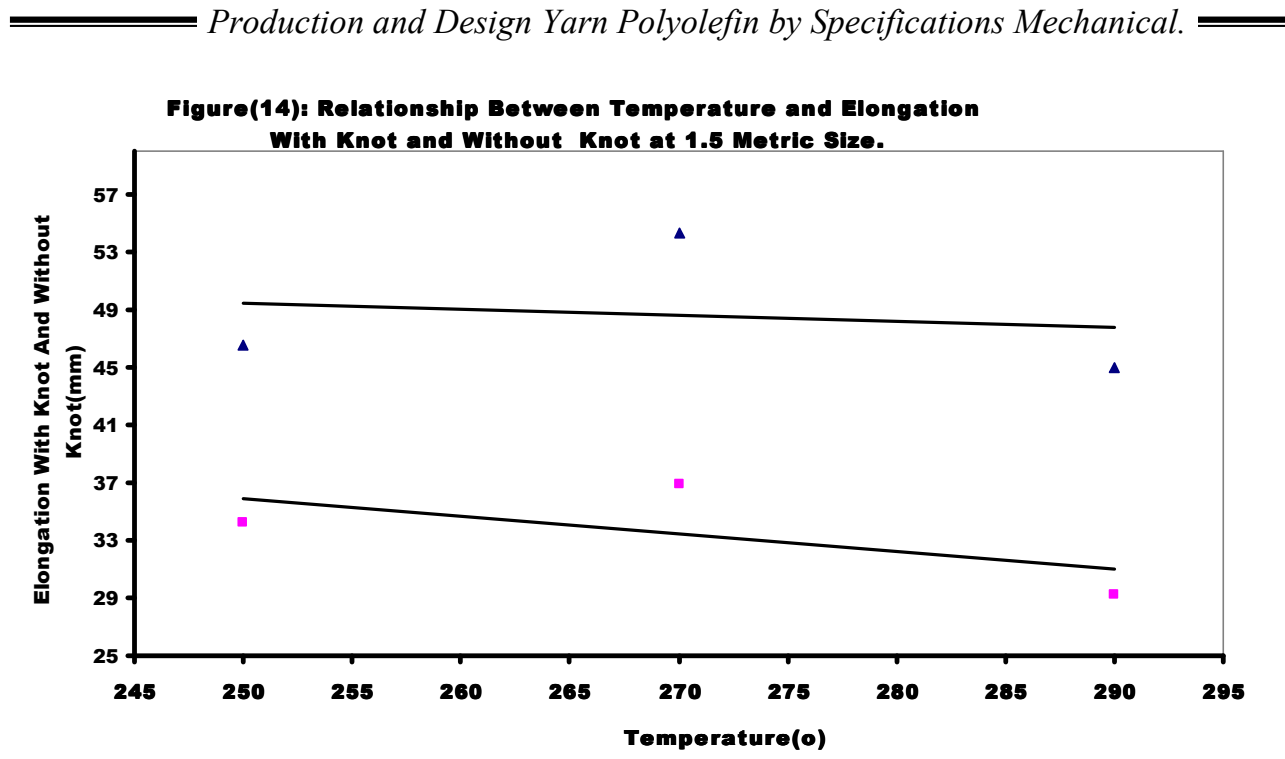

Figure (14) shows Relationship Between Temperature And Elongation Without Knot At 1.5 Metric Size.

Represented the straight line equation of samples (H30-E39-A48)

Elongation without knot $\mathrm{y}=59.52-0.04 \mathrm{x} \quad \mathrm{r}=-0.2$

as the temperature decreases. It's found that Elongation without knot increases.

It's also found that the correlation factor is $\mathrm{r}=-0.2$ which indicates that there is a an inverse relation between temperature and Elongation without knot.

And also Figure(14) shows Relationship Between Temperature And Elongation With Knot At 1.5 Metric Size.

Represented the straight line equation of samples (H30-E39-A48)

Elongation with knot $\mathrm{y}=67.10-0.13 \mathrm{x} \quad \mathrm{r}=-0.6$

as the temperature increases. It's found that Elongation with knot increases also.

It's also found that the correlation factor is $\mathrm{r}=-0.6$ which indicates that there is an inverse relation between temperature and Elongation with knot. 
As a result from increase temperature leads to decrease elongation of poly propylene suture with knot.

When temperature of poly propylene suture increase leads to decrease elongation without knot as a result of change in passage of polypropylene material in screw melt spinning. of

When temperature decrease with increase passage of poly propylene material in screw at 2.5 METRIC SIZE diameter leads to that poly propylene suture not reached to the demanding temperature so leads to decrease elongation without knot .

When passage of poly propylene material in screw decrease at 1.5 METRIC SIZE

Leads to reached to the demanding temperature so leads to decrease elongation without knot.

\section{8-2-4: Relationship Between Diameter And Elongation With Knot And Without Knot At Temperature (240:265 0C).}

Table(14): Relationship Between Diameter And Elongation With Knot And Without Knot At Temperature $\left(240: 265^{\circ} \mathrm{C}\right)$.

\begin{tabular}{||c|c|c|c||}
\hline $\mathbf{N}$ & $\begin{array}{c}\text { Code Of } \\
\text { Sample }\end{array}$ & $\begin{array}{c}\text { Elongation Without knot } \\
(\mathbf{m m}) \\
\Delta\end{array}$ & $\begin{array}{c}\text { Elongation With } \\
\text { Knot (mm) }\end{array}$ \\
\hline 1 & H-28 & 52.472 & 34.032 \\
\hline 2 & H-29 & 48.6964 & 33.32 \\
\hline 3 & H-30 & 46.568 & 34.1888 \\
\hline
\end{tabular}




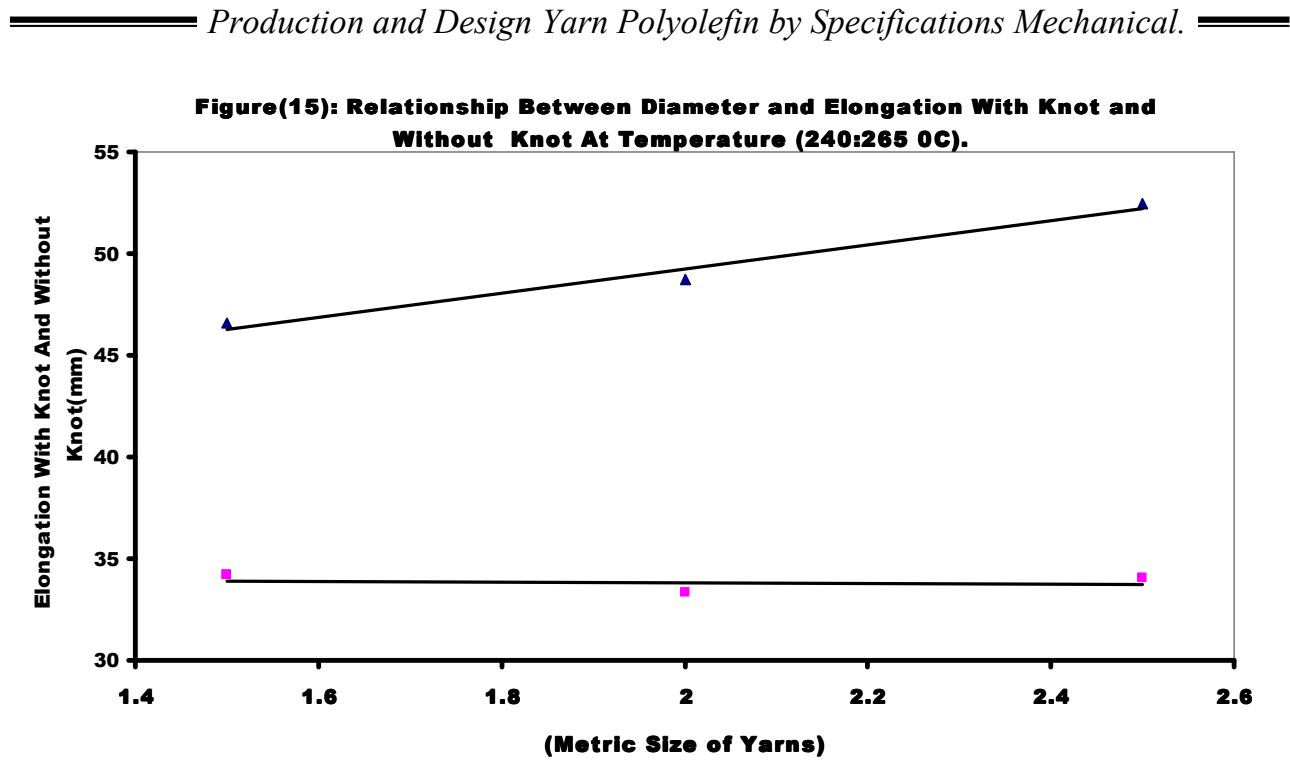

Figure(15) shows Relationship Between Diameter And Elongation Without Knot At Temperature $\left(240: 265^{\circ} \mathrm{C}\right)$.

Represented the straight line equation of samples (H28- H29- H30)

Elongation without knot $\mathrm{y}=37.16+5.9 \mathrm{x} \quad \mathrm{r}=0.9$

as the Diameter increases. It's found that Elongation without knot increases also.

It's also found that the correlation factor is $\mathrm{r}=0.9$ which indicates that there is a strong proportional relation between Diameter and Elongation without knot.

These result indicate the highest elongation without knot at Diameter 2.5 metric size and least elongation without knot Diameter 1.5 metric size and these result from when Diameter increase the elongation without knot increase because increase cross section. And also Figure(15) shows Relationship Between Diameter And Elongation With Knot At Temperature $\left(240: 265{ }^{\circ} \mathrm{C}\right)$.

Represented the straight line equation of samples $\quad(\mathrm{H} 28-\mathrm{H} 29-\mathrm{H} 30)$

Elongation with knot $\mathrm{y}=34.16-0.16 \mathrm{x} \quad \mathrm{r}=-0.2$

as the Diameter increases. It's found that Elongation with knot increases also. 
It's also found that the correlation factor is $r=-0.2$ which indicates that there is an inverse relation between temperature and Elongation with knot.

\section{8-2-5: Relationship Between Diameter And Elongation With Knot And Without Knot At Temperature (260:285 0C).}

Table(15): Relationship Between Diameter And Elongation With Knot And Without Knot At Temperature $\left(260: 285^{\circ} \mathrm{C}\right)$.

\begin{tabular}{|c|c|c|c||}
\hline $\mathbf{N}$ & $\begin{array}{c}\text { Code Of } \\
\text { Sample }\end{array}$ & $\begin{array}{c}\text { Elongation Without knot } \\
(\mathbf{m m})\end{array}$ & $\begin{array}{c}\text { Elongation With } \\
\text { Knot }(\mathbf{m m})\end{array}$ \\
\hline 1 & $\mathbf{E}-37$ & $\mathbf{5 8 . 1 8}$ & 35.9 \\
\hline 2 & E-38 & 76.68 & 41.94 \\
\hline 3 & E-39 & 54.346 & 36.926 \\
\hline
\end{tabular}

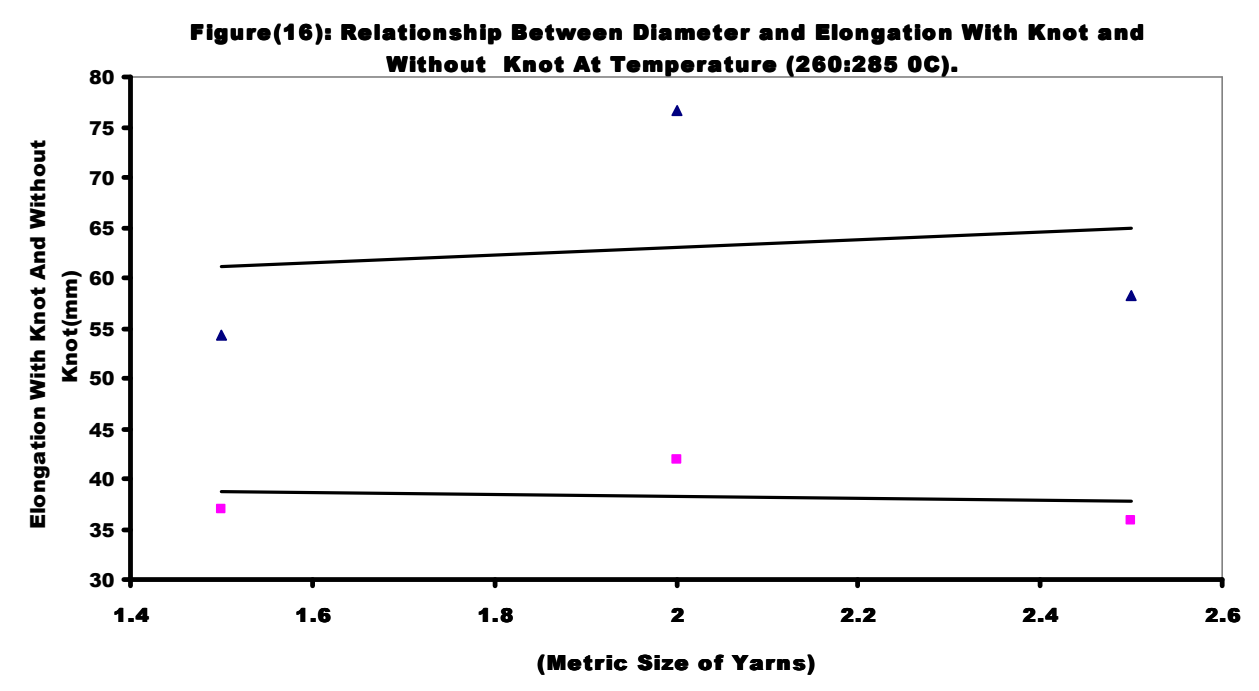

Figure(16) shows Relationship Between Diameter And Elongation Without Knot At Temperature $\left(260: 285^{\circ} \mathrm{C}\right)$.

Represented the straight line equation of samples (E37- E38- E39)

Elongation without knot $\mathrm{y}=55.40+3.83 \mathrm{x} \quad \mathrm{r}=0.2$

as the Diameter increases. It's found that Elongation without knot increases also. 
It's also found that the correlation factor is $\mathrm{r}=0.2$ which indicates that there is a proportional relation between Diameter and Elongation without knot.

These result indicate the highest elongation without knot at Diameter 2.5 metric size and least elongation without knot Diameter 1.5 metric size and these result from when Diameter increase the elongation without knot increase because increase cross section.

And also Figure(16) shows Relationship Between Diameter And Elongation With Knot At Temperature $\left(260: 285^{\circ} \mathrm{C}\right)$.

Represented the straight line equation of samples (E37- E38- E39)

Elongation with knot $\mathrm{y}=40.31-1.03 \mathrm{x} \quad \mathrm{r}=-0.2$

as the Diameter increases. It's found that Elongation with knot increases also. It's also found that the correlation factor is $r=-0.2$ which indicates that there is an inverse relation between temperature and Elongation with knot.

As a result from increase temperature leads to decrease elongation of poly propylene suture with knot. as a result of change in passage of polypropylene material in screw in melt spinning. of

\section{8-2-6: Relationship Between Diameter And Elongation With Knot And Without Knot At Temperature (280:305 0C).}

Table(16): Relationship Between Diameter And Elongation With Knot And Without Knot At Temperature $\left(280: 305^{\circ} \mathrm{C}\right)$.

\begin{tabular}{||c|c|c|c||}
\hline \hline N & $\begin{array}{c}\text { Code Of } \\
\text { Sample }\end{array}$ & $\begin{array}{c}\text { Elongation Without knot } \\
(\mathbf{m m}) \\
\Delta\end{array}$ & $\begin{array}{c}\text { Elongation With } \\
\text { Knot }(\mathbf{m m})\end{array}$ \\
\hline \hline 1 & $\mathrm{~A}-46$ & 46.956 & 32.0436 \\
\hline 2 & $\mathrm{~A}-47$ & 43.8152 & 31.078 \\
\hline 3 & $\mathrm{~A}-48$ & 44.9538 & 29.2016 \\
\hline
\end{tabular}




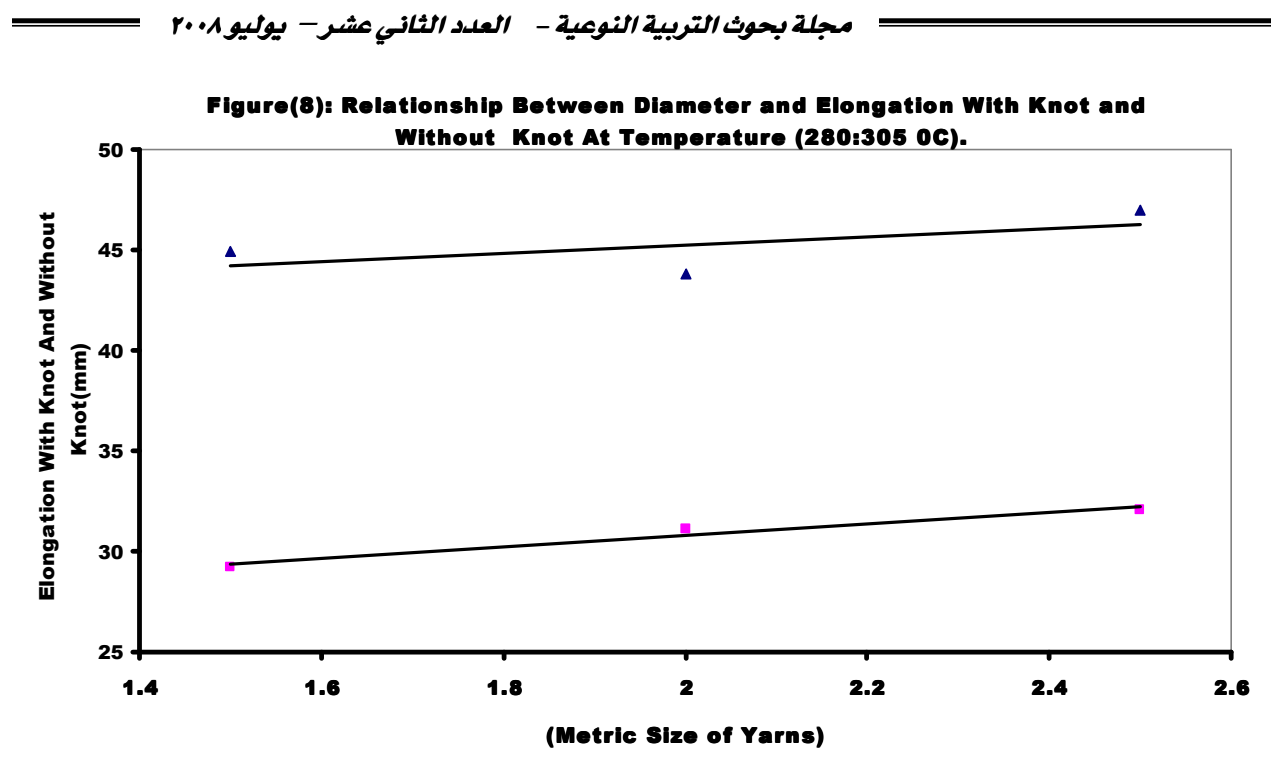

Figure(17) shows Relationship Between Diameter And Elongation Without Knot At Temperature $\left(280: 305^{\circ} \mathrm{C}\right)$.

Represented the straight line equation of samples (A46- A47- A48)

Elongation without knot $\mathrm{y}=41.24+2.002 \mathrm{x} \quad \mathrm{r}=0.6$

as the Diameter increases. It's found that Elongation without knot increases also.

It's also found that the correlation factor is $r=0.6$ which indicates that there is a proportional relation between Diameter and Elongation without knot.

These result indicate the highest elongation without knot at Diameter 2.5 metric size and least elongation without knot Diameter 1.5 metric size and these result from when Diameter increase the elongation without knot increase because increase cross section.

And also Figure(17) shows Relationship Between Diameter And Elongation With Knot At Temperature $\left(280: 305^{\circ} \mathrm{C}\right)$.

Represented the straight line equation of samples (A46- A47- A48)

Elongation with knot $\mathrm{y}=25.09-2.84 \mathrm{x} \quad \mathrm{r}=0.9$

as the Diameter increases. It's found that Elongation with knot increases also. It's also found that the correlation factor is $\mathrm{r}=0.9$ which indicates that there is a strong proportional relation between temperature and Elongation with knot. 
These result indicate the highest elongation with knot at Diameter 2.5 metric size and least elongation with knot Diameter 1.5 metric size and these result from when Diameter increase the elongation with knot increase because increase cross section.

\section{8-2-7: Comparison Between Diameter And Elongation With Knot And Without Knot .}

Table(17): Comparison Between Diameter And Elongation With Knot And Without Knot.

\begin{tabular}{|c|c|c|c||}
\hline $\mathbf{N}$ & $\begin{array}{c}\text { Code Of } \\
\text { Sample }\end{array}$ & $\begin{array}{c}\text { Elongation Without knot } \\
(\mathbf{m m})\end{array}$ & $\begin{array}{c}\text { Elongation With } \\
\text { Knot }(\mathbf{m m})\end{array}$ \\
\hline 1 & H-28 & 52.472 & 34.032 \\
\hline 2 & H-29 & 48.6964 & 33.32 \\
\hline 3 & H-30 & 46.568 & 34.1888 \\
\hline 4 & E-37 & 58.18 & 45.9 \\
\hline 5 & E-38 & 76.68 & 36.926 \\
\hline 6 & E-39 & 54.346 & 32.0436 \\
\hline 7 & A-46 & 46.956 & 31.078 \\
\hline 8 & A-47 & 43.8152 & 29.2016 \\
\hline 9 & A-48 & 44.9538 & \\
\hline
\end{tabular}

Figure(18): Comparison Between Diameter and Elongation With Knot And Without Knot .

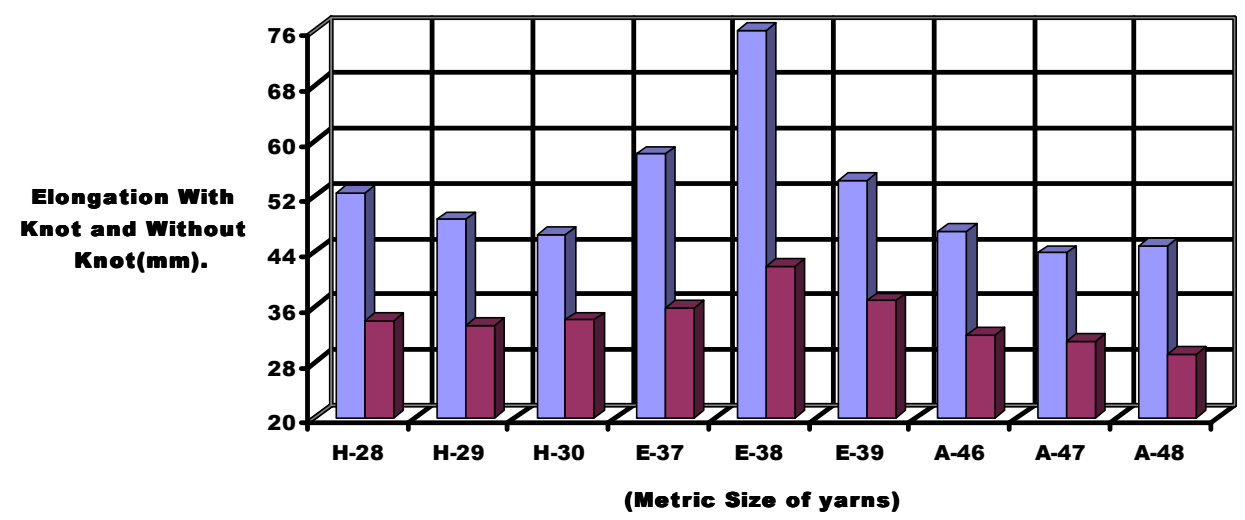

Figure(18) shows Comparison Between Diameter And Elongation Without Knot. The results show that least level of Elongation without knot achieved at A-47 which measured $43.82 \mathrm{~mm}$ at temperature (260-270-270-280$285^{\circ} \mathrm{C}$ ) and Diameter 2 metric size. 
The second sample of Elongation without knot achieved at A-48 which measured $44.95 \mathrm{~mm}$ at temperature $\left(280-290-290-300-305^{\circ} \mathrm{C}\right)$ and diameter 1.5 metric size.

The third sample of Elongation without knot achieved at $\mathrm{H}-30$ which measured $46.57 \mathrm{~mm}$ at temperature $\left(280-290-290-300-305^{0} \mathrm{C}\right)$ and diameter 1.5 metric size.

And also Figure(18) shows Relationship Between Diameter And Elongation With Knot.

The results show that least level of Elongation with knot achieved at A-48 which measured $29.20 \mathrm{~mm}$ at temperature $\left(280-290-290-300-305^{\circ} \mathrm{C}\right)$ and diameter 1.5 metric size.

The second sample of Elongation with knot achieved A-47 which measured $31.08 \mathrm{~mm}$ at temperature $\left(260-270-270-280-285^{\circ} \mathrm{C}\right)$ and Diameter 2 metric size.

The third sample of Elongation with knot achieved at A-46 which measured $32.04 \mathrm{~mm}$ at temperature $\left(240-250-250-260-265^{\circ} \mathrm{C}\right)$ and diameter 1.5 metric size.

\section{SUMMARY}

Textile has swept over new filed in the last three decades. It has been used indifferent fields, Such as agriculture, Industry and medicine, with the aim of improving the performance efficiency and reducing costs. This industry has recently achieved a tremendous success in medical fields thus, it has been used in designing and manufacturing polyproplene suture.

our studies reveal that we must have our medical equipments especially suture, our studies also reveal that local industry for medical equipment not present especially polyproplene suture which leads to increase import suture from out side and also decrease researches specialized for these reasons.

This research covering the theoretical, practical and experimental aspects of the subject. These research depend on analytical approach of the practical aspects of sutures.

The methodology of the research depends on the experimental analytical approach. 
The Objectives Of Research to:

1-Study the effect Of Temperature In Melt Spinning Of Polypropylene that affect Properties of Suture .

2- Study the effect of Diameter Suture Polypropylene that affect Properties Suture .

The Following Results Were Identified:

1- There is a direct relationship between tensile Strength without knot and temperature of melt spinning of polypropylene suture.

2- There is a direct relationship between tensile Strength with knot and temperature of melt spinning of polypropylene suture.

3-There is a direct relationship between tensile Strength without knot and diameter of polypropylene suture.

4-There is a direct relationship between tensile Strength with knot and diameter of polypropylene suture.

5-There is an inverse relationship between elongation without knot and temperature of melt spinning of polypropylene suture.

6-There is an inverse relationship between elongation with knot and temperature of melt spinning of polypropylene suture.

7-There is a direct relationship between elongation without knot and diameter of polypropylene suture.

7-There is no relationship between elongation with knot and diameter of polypropylene suture. 


\section{References:}

1- PROF.V.A. SHENAL PROF . OF TEXTILE CHEMISTRY OF UNIVERSITY OF BOMBAY, TECHNOLOGY OF TEXTILE PROCESSING , TEXTILE FIBERS, THIRD EDITION VOLUME:1,PAGE:394,395- YEAR:1991.

2-SARA J.KADOLPH, ANNA L. LANGFORD, NORMA HOLLEN, JANE SADDLER, LOWA STATE UNIVERSITY, TEXTILES, SEVENTH EDITION, PAGE :117, YEAR:1995.

3-ALFONSO R.GENNARO , THE SCIENCE AND PRACTICE OF PHARMACY-NINETEENTH EDITION-VOLUME 2-CHAPTER:108 -USAPAGE:1880- YEARS:1995.

4- R. M. KIRK - SURGICAL OPERATION - FIRST PUBLISHED -PRINTED IN GREAT BRITIAN BY PITMAN PRESS LTD., BATH U.K-PAGE: 3- YEAR: 1979.

5- BATES TOM.- OLANE'S HOSPITAL - POLYPROPLENE SUTURESBRITISH MEDICAL JOURNAL-VOLUM:10-PART:1-PAGE:615-YEAR:10 MARCH 1973.

6-ERIC W.TAYLOR -INFECTION IN SURGICAL PRACTICE-PUBLISHE IN THE UNITED STATESBY OXFORD -U.S.A-PAGE:21,22-YEAR:1992.

7-UNITED STATES PHARMACOPOEIA - NINETEENTH EDITION -U.S.A PAGE: 1586- YEAR: 2000.

8-UNITED STATES PHARMACOPOEIA - NINETEENTH EDITION -U.S.A PAGE: 1586- YEAR: 2000.

9-EUROPEAN PHARMACOPOEIA - THIRD EDITION - PAGE: 1567YEAR:1998.

10- BRIAN A. MAURICE- SURGERY FOR GENERAL PRACTI TIONERS FIRST EDITION -CASTLE HOUSE PUBLICATIONS- UNITED KINGDOM -PAGE: 108- YEAR: 1989.

11-ETHICON COMPANY-ETHICON CATALOGUE- SUTURES MATERIAL SECTION - U.K- PAGE: 1991.

12 -KANT Y. LIN, M.D., PROFESSOR OF PLASTIC SURGERY, UNIVERSITY OF VIRGINIA HEALTH SYSTEMS, AND WILLIAM B. LONG III, M.D, MEDICAL DIRECTOR, TRAUMA SPECIALISTS, LLP, SCIENTIFIC BASIS FOR THE SELECTION OF SURGICAL NEEDLES AND SUTURES, U.S.A,YEARS: MARCH 2005.

13-KNIGHT CD \& GRIFFEN FD - ABDOMINAL WOUND CLOS URE WITH ACONTINOUS MONOFILAMENT POLYPROPYLENE SUTURE 
EXPERIENCE WITH 1.000 CONSECUTIVE CASES-ARCH- SURGERYPART:118- VOLUME: 11-PAGE: 1305, 1308- YEAR: 1983.

14- GASPAR MR., MOVIUSH J., ROSENTALJ J., BELL DD. \& LEMIRE GG. PROLENE SUTURES ARE NOT ASINGHICANT FACTORINANASTONOTIC FALSE ANERYSNS-VOLUME: 146 -PAGE: 216 - YEAR: 1983.

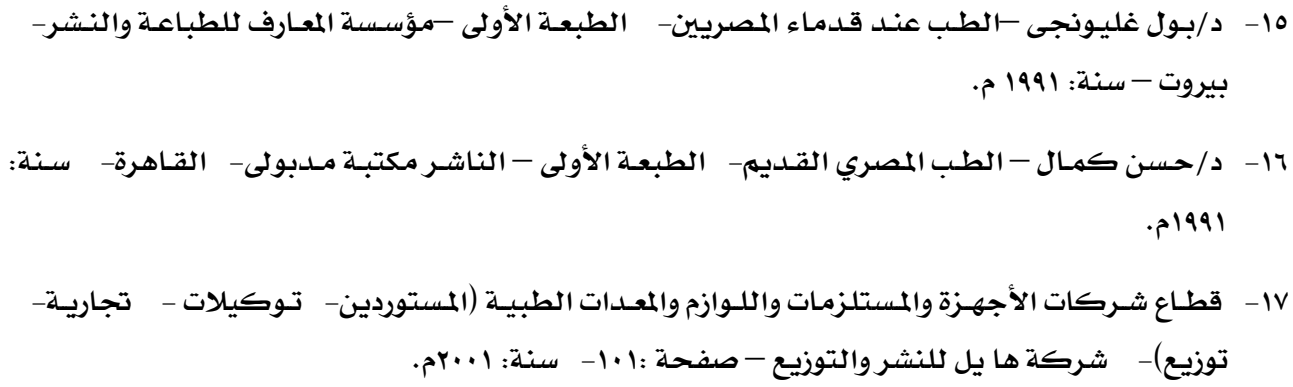

